\title{
Only the brave? Risk and time preferences of decision makers and firms' investment in worker training
}

Citation for published version (APA):

Jansen, A., Pfeifer, H., \& Raecke, J. (2017). Only the brave? Risk and time preferences of decision makers and firms' investment in worker training. Maastricht University, Graduate School of Business and Economics. GSBE Research Memoranda No. 004 https://doi.org/10.26481/umagsb.2017004

Document status and date:

Published: 01/03/2017

DOI:

10.26481/umagsb.2017004

Document Version:

Publisher's PDF, also known as Version of record

\section{Please check the document version of this publication:}

- A submitted manuscript is the version of the article upon submission and before peer-review. There can be important differences between the submitted version and the official published version of record.

People interested in the research are advised to contact the author for the final version of the publication, or visit the DOI to the publisher's website.

- The final author version and the galley proof are versions of the publication after peer review.

- The final published version features the final layout of the paper including the volume, issue and page numbers.

Link to publication

\footnotetext{
General rights rights.

- You may freely distribute the URL identifying the publication in the public portal. please follow below link for the End User Agreement:

www.umlib.nl/taverne-license

Take down policy

If you believe that this document breaches copyright please contact us at:

repository@maastrichtuniversity.nl

providing details and we will investigate your claim.
}

Copyright and moral rights for the publications made accessible in the public portal are retained by the authors and/or other copyright owners and it is a condition of accessing publications that users recognise and abide by the legal requirements associated with these

- Users may download and print one copy of any publication from the public portal for the purpose of private study or research.

- You may not further distribute the material or use it for any profit-making activity or commercial gain

If the publication is distributed under the terms of Article $25 \mathrm{fa}$ of the Dutch Copyright Act, indicated by the "Taverne" license above, 
Anika Jansen, Harald Pfeifer, Julia Raecke

Only the brave? Risk and time preferences of decision makers and firms' investment in worker training

RM/17/004

\section{GSBE}

Maastricht University School of Business and Economics

Graduate School of Business and Economics

P.O Box 616

NL-6200 MD Maastricht

The Netherlands 


\title{
Only the brave? Risk and time preferences of decision makers and firms' investment in worker training
}

\author{
Anika Jansen ${ }^{a}$ \\ Harald Pfeifer ${ }^{a, b}$ \\ Julia Raecke $^{a}$
}

$a$ Federal Institute for Vocational Education and Training (BIBB), Bonn

$b$ Research Centre for Education and the Labour Market (ROA), Maastricht

March 2017

\begin{abstract}
*
In this paper, we study the relation between decision makers' preferences and training investments of their firms. First, we develop a theoretical framework, which takes the possibility into account that individual preferences of decision makers may influence firm behavior with respect to training. We then develop and test the hypothesis that the willingness to take risks or the preference for future profits of decision makers is positively related and procrastination negatively related to firms' investment in worker training. Using unique firm-level data, including both person-level preference measures and firm-level information about training costs, we find empirical support for our hypothesis. Training investment is higher in firms with risk-inclined decision makers and lower in firms with procrastinating decision makers. The preference for future profits is relevant for training participation and the number of trained workers, but not for the training investment per worker. The results imply that firms have scope to adjust their profit-maximizing strategies by taking the individual preferences of their decision makers into account.
\end{abstract}

JEL Classification: J24, J31

Keywords: Risk and time preferences, training investment, profit maximization

* We thank Bart Golsteyn, Ruud Gerards, Gudrun Schönfeld and Günter Walden for helpful comments and suggestions, and Felix Wenzelmann for his work on the survey data. 


\section{Introduction}

The importance of personal preferences for economic and educational choices has been highlighted in a quickly growing strand of literature. Among others, risk attitudes and time preferences have been identified as important determinants for individual economic choices (Camerer and Loewenstein, 2004; Dohmen et al., 2009, 2011). At the same time, some studies focus on the relation between manager characteristics and the firm-level decision making (e.g. Bertrand and Schoar, 2003; Wang et al. 2016). However, merging the two strands of literature, few works provide empirical evidence for the link between decision makers' preferences and firm-level investment.

This paper aims to contribute to the literature by analyzing this link using large-scale survey data. It addresses the question of how risk attitudes and time preferences of decision makers relate to firm investment in the human capital of their workers. It argues that human capital investment in the form of worker training is an ideal case for studying this relationship because this type of investment is prone to risk due to the potential mobility of workers (Becker, 1962).

The data for the empirical analysis stems from a unique firm-level survey providing both detailed information on firm investment in worker training and measures for the risk attitudes and time preferences of respondents who have decision-making power in the firm (i.e. owners/partners, managers, heads of a HRM department). Risk attitudes are surveyed in the form of a direct assessment, i.e. the respondents report their willingness to take risks. This procedure of measuring risk attitudes has been identified as the most valid in experimental settings (Dohmen et al., 2011). The assessment of individuals' time preference relies on two different concepts. The first is a concept of procrastination, i.e. the respondents report their tendency to delay action although it would be better to solve the issue immediately. The second is the concept of discounting, i.e. individuals report their willingness to give up something that is beneficial for them today (e.g. consumption) in order to obtain a profit in the future.

First, we draw on a simple profit-maximization model for firms and introduce decision makers' economic preferences as factors into the model. Based on this framework, we expect that higher personal preferences for risk and future profits are positively related to a firm's training investment. Conversely, we expect a higher level of procrastination to reduce the training investment in a firm.

In the empirical analysis, we focus on three different training outcomes: the training probability of a firm, the number of workers trained and the amount of resources invested per trained worker. The findings suggest that the preferences of decision makers in a firm are important determinants for firm-level training outcomes. The higher the decision maker's preference for future profits, the higher the likelihood that the firm provides training and the 
more workers are trained. Furthermore, a decision maker's willingness to take risks relates positively to the firm's training investments. With respect to time preferences, the results suggest a negative relation between a decision maker's procrastination and the firm's training investments.

The analysis in this paper contributes to the literature by showing that firm-level decisions may be contingent on manager-level preferences, a link that has rarely been studied based on large-scale empirical data. The results have strong implications for theoretical models explaining strategic firm behavior in competitive markets.

This paper provides a brief discussion of the relevant literature in the following section. Section 3 then focuses on theoretical background and develops a framework that includes individual preferences in a firm-level profit maximization setting. Section 4 describes the data source and variable construction for the empirical analysis. Section 5 discusses the results and provides robustness tests. Section 6 concludes the paper with some policy and practice implications.

\section{Literature}

This section first discusses literature about economic preferences and their role in determining individual and firm decisions. It then focuses on studies analyzing worker training and its risks from a firm's perspective.

\subsection{Economic preferences and their influence on economic behavior}

The literature discusses different types of individual preferences and their significance for economic decision making. When addressing economic investment decisions, time preferences and risk attitudes in particular have been at the center of attention (see e.g. Falk et al., 2015). Risk attitudes describe the personal preferences of individuals to take risks (Kahneman and Riepe, 1998; Sabater-Grande and Georgantzis, 2002), while time preferences refer to the tradeoff decision between future and current benefits (Camerer and Loewenstein, 2004). Even though value discounting of risky assets relies on a different cognitive process than the value discounting of future assets (Green and Myerson, 2004), many empirical studies consider both concepts due to their strong correlation: Investing in a future asset is always associated with a certain positive risk that the desired outcome cannot be realized (Borghans et al., 2008; Andersen et al., 2008a). Both, time and risk preferences have a strong influence on individual behavior.

In general terms, the literature shows that risk attitudes are relevant for individual investment behavior. Risk prone individuals invest significantly more in risky assets concerning portfolio choices (Dohmen et al., 2011; Guiso and Paiella, 2008; Kapteyn and Teppa, 2011). 
Moreover, they seem to be more optimistic concerning the investment of primary capital and are more likely to become self-employed (Armstrong and Huck, 2010; Caliendo et al., 2014; Skriabikova et al., 2014). The literature further shows that risk-averse individuals choose occupations with lower wage risks, for example occupations in the public sector, meaning that such people prefer certainty regarding returns for their working efforts (Bonin et al., 2007; Guiso and Paiella, 2008). Risk preferences are also relevant when it comes to investments in the individual's human capital. Brown et al. (2006) provide evidence that risk-averse individuals show a lower educational attainment than risk-inclined individuals because the former are less willing to invest in their education.

Individual time preferences also relate to actual behavior in the real world. Golsteyn et al. (2014) find that high individual discount rates are related to lower incomes at middle age, which appears to be mediated by early human capital investments. Furthermore, patient individuals seem to actively choose occupations with steeper wage dynamics, indicating that they accept the latency until higher returns emerge. People even change occupations when realizing their preferences are not in line with the occupational criteria (Fouarge et al., 2014). When examining the explaining factors for varying participation in workers' training, Fouarge et al. (2013) find that low educated workers participate less in training than highly-educated workers. The authors provide evidence that this difference is partly due to a lower future orientation of less educated workers, leading to a decrease in their willingness to participate in training.

Experimental studies have investigated time preferences and their dependence on the timing and amount of the reward in more detail. Unlike traditional economic theories would assume, the studies find that time preferences are not constant. The most prevalent anomaly from rational decision making is the concept of hyperbolic discounting, which describes the decline of discount rates over time (see Frederick et al., 2002 for a review). Hyperbolic discounting implies that individuals become more patient when choosing between two delayed options as compared to choosing between an immediate and a delayed option. In this context, Benhabib et al. (2009) find that individuals are strongly influenced by a present bias and that discount rates decline with delay and amount. The strong tendency toward the present could partly be explained by procrastination and self-control problems. Accordingly, Reuben et al. (2015) find that the preference for an individual's immediacy is strongly linked to their tendency to procrastinate.

Via the decisions individuals take, risk attitudes and time preferences can also have an influence on the economic output. Tanaka et al. (2010) provide evidence for a correlation between Vietnamese villages' wealth and the risk attitudes of their inhabitants. Wealthy villages are associated with a lower loss aversion and lower discount rates. The mechanism driving this relation is that risk aversion and impatience leads people to avoid establishing businesses and 
reduces the likelihood that they will invest in their children, which in turn diminishes the latter's chance for high returns in the future. However, there is also evidence that a strong tendency for riskiness is not always associated with the highest return. Caliendo et al. (2014) find that entrepreneurs with a medium risk tolerance are the most successful.

\subsection{Individual risk preferences and firm behavior}

Can the findings of risk- and time-preference effects be transferred to firms' investment decisions? As firms' decisions are also made by human beings, the former could also be influenced by individual biases and personal preferences. Evidence from the field of organization theory and behavior shows that strategies of firms are often related to the values of their managers, who take decisions on behalf of the firm. The upper echelons theory, for example, states that general characteristics of managers affect firm strategies and firm performance (Hambrick and Mason, 1984). Bertrand and Schoar (2003) provide evidence for significant influences of managers' personalities on firms' policy decisions, such as investment behavior, and even indicate the existence of robust managing style patterns. Armstrong and Huck (2010) argue that influences, such as human preferences, may be the reason why firms do not always strive for profit maximization. The authors discuss positive and negative reciprocity as central factors when deciding how to participate in market processes, such as decisions concerning merging, collusion, competing and product pricing.

Recent evidence in the field of personnel psychology (Wang et al. 2016) finds that CEOs' characteristics such as age, tenure, career experience, and aspects of the managers' personalities, such as CEOs' positive self-concept, are significantly related to a firm's strategic actions, among them decisions on acquisitions, capital investments, product innovation and, more in general, risk taking.

Furthermore, empirical evidence suggests that managers' risk attitudes affect firm behavior. Examining the relation between early-life experience of CEOs' and their cooperate decisions, Bernile et al. (2017) find that the mechanism is channeled by CEOs' risk attitudes affecting corporate risk taking. Rashad Abdel-Khalik (2014) investigates the relationship between risk preferences of managers and their investment behavior. The author argues that top managers are pivotal for the strategies taken by the firm, among those the strategies concerning investments. The study shows, for example, that firms with managers who are risk inclined invest significantly more in research and development. For developing countries, Kremer et al. (2013) or Pattillo and Soderbom (2000) find a relation between risk attitudes of firm managers and firm behavior. The studies suggest that firms with risk-inclined owners invest more and grow faster as compared to firms with risk-averse managers. Tanaka and Sawada (2015) elicit risk preferences through experiments with managers from textile and garment firms in Lao PDR. 
They investigate the relation between risk preferences and financing strategies and investment in their factories' safety measures against fires and injuries. The results show that risk-averse managers are less likely to borrow loans from the bank, which leads to lower asset levels. However, they tend to invest more in safety measure than risk-inclined managers. Cucculelli and Ermini (2013) find for a sample of Italian entrepreneurs that risk-inclined managers select products that have in turn a positive effect on firm growth. Furthermore, Graham et al. (2013) find that risk-tolerant CEOs are more likely to make mergers and acquisitions.

Summing up, several studies suggest a non-trivial link between risk attitudes of managers and cooperate behavior, including investment behavior. With respect to investments in human capital, Jansen (2016) provides empirical evidence for managers' altruism and time preferences relating positively to the financing of apprenticeships in firms. However, the relation between investments in human capital and risk preferences has not been discussed in the literature.

\subsection{Firms' training investment as an example for "risky" investment}

One important decision that firms are facing is the question of whether and how much to invest in their workers' human capital. Providing continuous training can yield substantial and direct productivity returns to the firm (see Leuven, 2005 for a general overview). Moreover, the literature provides evidence for indirect effects such as spillover effects (De Grip and Sauermann, 2012). However, as worker training is costly for the firm, there is a time and risk dimension. First, training returns are by definition generated in the future. Second, there is a certain positive risk that the returns to training cannot be realized at all.

In the following, we briefly discuss why the realization of training returns is prone to substantial risks. The most important risk is that workers do not stay in the firm after having received their training. Workers might quit because of various external reasons or they leave due to (wage) incentives to take on a job in another firm. Thereby, leaving could either be the result of a self-initiated job search or the worker is poached by another firm. ${ }^{1}$

Another risk associated with training investments is that the firm cannot be fully certain about the appropriateness and quality of training provided (e.g. the trainer-training-trainee match). Negative outcomes, such as lacking learning transfer or even adverse training effects, are also possible (Holladay and Quiñones, 2008). Additionally, in contrast to physical capital, human capital cannot be separated from its owner, meaning that there is a reduced scope for a flexible interchange of human capital between workers (Levhari and Weiss, 1974). Investing in new technical devices, for example, offers flexibility because it can be passed on from one

\footnotetext{
${ }^{1}$ With respect to the poaching, Muehlemann and Wolter (2011) find that firms provide less apprenticeship training in densely-populated areas because firms are more afraid of poaching in dense labor markets.
} 
worker to another when necessary. Knowledge and skills, however, cannot be transferred as easily.

Considering this spectrum of different types of risks related to investment in human capital, the next section presents a model in which risk and time preferences have an influence on the training investments of firms. While risk-averse decision makers should perceive the risk as rather threatening, we assume risk prone managers to perceive them as an opportunity. Moreover, we assume that decision makers with a long-term focus are more likely to invest in workers' training than decision makers with a short-term focus.

\section{Theoretical framework}

Our starting point is a simple theoretical model on the optimal amount of training that firms provide to their workers. Each firm can decide whether it provides their workers with continuous training and if they do, they can decide how much training to provide. Providing more training will lead to higher returns to the firm, but will also be associated with higher costs. Depending on the specific form of the cost and benefit function, an optimal amount of training investment can be derived. The firms can decide upon both the quality and quantity of training, which will each be subsumed under the amount of training.

We first show that the optimal investment in workers' training is a decision that involves a clear time and risk dimension. In a second step, we discuss how the time preferences and risk attitudes of decision makers can be integrated in this model.

\subsection{Optimal amount of training}

As discussed above, many studies have explained why firms can generate returns from training. For this model, we do not differentiate between the channels through which the training returns are generated. It suffices to know that, on average, assuming imperfect competition and some degree of specific human capital, there will be some post-training returns. In the model, we assume that training is technologically general but that frictions lead to a market wage lower than the worker's productivity. Let us assume that training returns $(b)$ depend on the amount of training and $b(t)^{\prime}>0 ; b(t)^{\prime \prime}<0$.

Nonetheless, there is a certain positive probability for the firm that post-training returns cannot be realized. Therefore, the probability that the returns can be realized is given by $p$. This may occur because the worker separates with an exogenous probability from the training firm or because, albeit her course attendance, the worker did not learn the relevant knowledge and skills. Moreover, future returns must be discounted with the discount rate $r$ to obtain their present value (Borjas, 2008). 
The costs for training are given by $c(t)$ and we assume that they are linear and increasing in the amount of training. This also implies that average training costs will be equal to marginal training costs. Firms want to maximize their profits and the profit function of firms can be written as:

$$
\pi=p \cdot \frac{1}{(1+r)} \cdot b(t)-c(t)
$$

The optimal amount of training is given, if the first order condition is fulfilled:

$$
p \cdot \frac{1}{(1+r)} \cdot b^{\prime}(t)=c^{\prime}(t)
$$

Plugging in $f \cdot \mathrm{t}^{\alpha}$ for the training returns, with $\alpha$ between 0 and 1 and $\mathrm{f}$ sufficiently high that the optimal training level is positive (i.e. at least $1^{2}$ ), and assuming that $c^{\prime}(t)=1$, we obtain the optimal amount of training as given by: ${ }^{3}$

$$
t^{*}=\left(\frac{f \cdot \alpha p_{b}}{1+r}\right)^{1 /(1-\alpha)}
$$

The equation shows that the optimal amount of training depends on the discount rate $r$, the probability to obtain the training returns $p_{b}$ and the degree of decreasing marginal utility of training $\alpha$. The higher a firm's discount rate the less training it would provide. Moreover, the more likely it can obtain the training returns, the more training it is willing to provide. Therefore, the decision on the optimal amount of training involves a time and risk dimension.

\subsection{The influence of decision makers' preferences on worker training}

The fundamental assumption that we make in this paper and that is backed up by the literature in Section 2.2 is that it is not the firm as an abstract entity that makes the investment decision but rather an individual who acts on behalf of the firm. We show that this assumption has certain implications for the optimal training decision in the firm. Although managers operating in a professional world will try to represent the firm's interest as well as they can, their individual preferences will influence the (training) decisions they take to some degree. More precisely, as we have shown that the training decision involves a clear time and risk dimension, we expect that the individual preferences regarding the time and risk have an influence on the optimal amount of training provided by the firm.

\footnotetext{
${ }^{2}$ The minimum level of $f$ is obtained by equating the optimal level of $\mathrm{t}^{*}$ with at least one and solving the equation for f: $f>\frac{1+r}{\alpha p}$.

${ }^{3}$ See Equations A1 in the appendix for the intermediate steps.
} 
The standard training models assume that firms and workers are risk-neutral and that there is no discounting (Leuven, 2005). Even though discounting is generally considered in the human capital literature when it comes to workers' individual training or educational decision (Borjas, 2008), the effect of individual discount rates on the behavior of firms is usually not explicitly taken into account. Nonetheless, when acknowledging in the model that the firms' profits are maximized by individuals, i.e. the decision makers within the firm, the literature on organizational behavior imply individual preferences to play a role.

To introduce this relationship in the model, the constant discount rate is replaced by a discount rate specific to the decision maker $\left(r_{D m}\right)$. To include risk attitudes in the model, we add an additional indicator (risk) as a factor for the probability that the training returns are realized. If this indicator is greater than one, an individual is "risk inclined". If the indicator is lower than 1, an individual is "risk averse". Risk aversion means that the certainty equivalent is greater than the expected return. The profit function from the decision makers' perspective is thus given by:

$$
\pi_{D m}=\operatorname{risk}_{D m} \cdot p \cdot \frac{1}{\left(1+r_{D m}\right)} \cdot b(t)-c(t)
$$

Again, plugging in $\mathrm{t}^{\alpha}$ for the training returns yields the optimal training investments, but this time they depend additionally on the individual time and risk preferences.

$$
t_{D m}^{*}=\left(\frac{\mathrm{f} \cdot \alpha r i s k_{D m} p}{1+r_{D m}}\right)^{1 /(1-\alpha)}
$$

The decision to provide worker training thus depends on the risk attitudes in the sense that risk-inclined managers will provide more training. Moreover, the training decision depends on the time preferences, in the sense that managers with a higher preference for future profits provide more training. ${ }^{4}$

For risk $k_{D m}=1$ and $r_{D m}=r$, the manager's training decision will be equal to the firm's optimal training decision. However, Equation 5 also shows that the more decision makers depart from risk neutrality and rational discount rates, the larger will be the distance from the optimal training decision from a firm's perspective.

\footnotetext{
${ }^{4}$ We acknowledge the possibility that, apart from training, other investment options exist for the decision maker in the firm. These could 'compete' with the investment in training. However, as some of the studies discussed in the literature section already address other investment options, this paper focuses solely on the investment in training.
} 
To illustrate this relationship, we plotted the marginal costs and returns from the firm's and the decision maker's perspective in Figure 1. The marginal costs are constant and the expected marginal returns are given by:

$$
\alpha \cdot \operatorname{risk}_{D m} \cdot p_{b} \cdot \frac{1}{\left(1+r_{D m}\right)} \cdot f \cdot t^{\alpha-1}
$$

The following figure shows how the chosen training decision changes according to the decision maker's risk preference (assuming time neutrality).

Assuming that the value for risk is below 1, Figure 1 shows that the decision maker would choose $\mathrm{t}_{D m 1}{ }^{*}$, i.e. a lower amount of training than $\mathrm{t}_{\text {firm }}{ }^{*}$, which would be optimal from the firm's perspective. Vice versa, if the decision maker was risk inclined with a value larger than 1 , the firm's realized amount of training would be $\mathrm{t}_{D m 2^{*}}$, an amount larger than the optimum $\mathrm{t}_{\text {firm }}{ }^{*}$. The respective figure could also be drawn for different types of time preferences (assuming risk neutrality).

Figure 1: Optimal amount of training from both the decision maker's $(\mathrm{Dm})$ and the firm's perspective, assuming risk neutrality, risk inclination and risk aversion of the decision maker

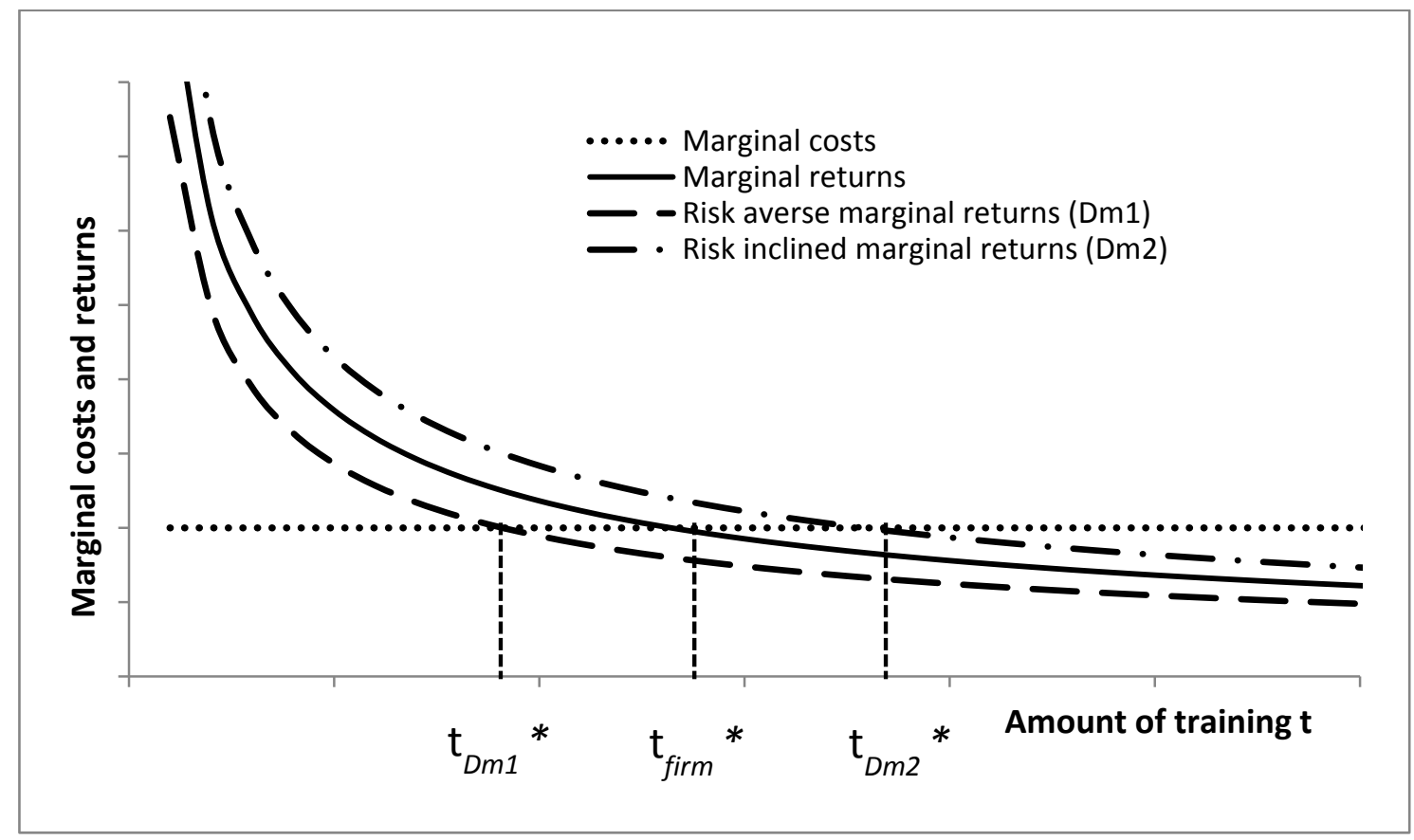

In the real world, the optimal training level is often unknown due to imperfect information about the future training benefits. Thus, even in case of risk neutrality and objective discount rates it may be the case that decision makers do not choose the optimal amount of training because they are not aware of the future benefits. Only when the optimal training investment is known under risk and time neutrality, preferences in one or the other direction would lead to a deviation from the optimal training decision. In this paper, we cannot test whether or to what 
extend risk and time preferences are related to a deviation of the optimal training decision. However, irrespective of information about the training optimum, we derive the following hypothesis on the relation between preferences and the amount of training:

1.) Firms with decision makers reporting a higher willingness to take risks invest more in their workers' training.

2.) Firms with decision makers reporting higher levels of procrastination invest less in their workers' training.

3.) Firms with decision makers reporting higher preferences toward the future invest more in their workers' training.

\section{Data and variables}

In this section, we describe the data base and the main dependent and independent variables for our empirical analysis.

\subsection{Data: Firm-level survey}

The data used for the empirical analysis in this paper stems from the BIBB Cost-Benefit Survey (BIBB CBS) of 2012/2013, which provides detailed information on both firms' investment in the training of skilled workers and the risk attitudes and time preferences of the survey respondents, who have decision-making power in the firm (e.g. owners/partners, managers and heads of a HRM department etc.). The questions for the measurement of training investment and the module on decision makers' preferences were implemented in the survey for the purpose of this analysis.

The survey was conducted in fall 2013 by means of personal interviews (CAPI). The fieldwork was organized by the infas Insitute for Applied Sciences, Bonn. The sample of firms stems from the firm register at the Federal Employment Agency. This register contains the addresses of all German establishments with at least one worker or apprentice who is subject to social security payments. The addresses were drawn as stratified by regions and according to whether or not they were engaging in apprentice training. For the analysis in this paper, we use firm-level probability weights to correct for disproportionate sampling due to stratification. ${ }^{5}$

The initial data set contains 3,636 firms. We exclude those records for firms that have missing values in one of the dependent or independent variables. A large part of the excluded firms (544) is removed, because the respondents did not have any decision-making power in the firm concerning the training activities and thus (through filtering) were not asked about their

\footnotetext{
${ }^{5}$ Details about the weighting procedure, non-response and survey methodology are provided in an unpublished report (Schiel et al., 2014), which is available upon request.
} 
preferences. Of the remaining 2,589 firms, 1,768 have trained at least one worker in the year 2012.

\subsection{Variables: Worker training}

The training indicators refer to a specific group of workers in the firm. More precisely, we ask for the provision of training for workers that have undergone a vocational training in a specific occupation and have not been recently hired. As such, we focus on continuing training (i.e. courses or seminars) of qualified workers with a specific occupational background. ${ }^{6}$ The advantage of this approach is that respondents have a clear definition of the reference group, which is very likely to improve the accuracy of the answers compared to the answers given for all the workers in the firm, regardless of qualification background and function. The respective occupation of the workers is included in the regression models as described below.

In the results section, we provide estimates for three different regressions, each with a different dependent variable. The first regression has the mere training participation (modeled as a dummy of 1/0) as an outcome. All firms that provided firm-financed training to workers in the year 2012 are coded ' 1 ', while firms without provided training are coded ' 0 '.

The second regression uses the number of workers that were trained over the course of 2012 as the dependent variable. Those firms not providing training thus train zero workers. All training firms reported the number of trained workers ranging from 1 to 1,300 . We interpret this variable as a count measure and thus apply a count-data regression model for estimates on the relation between preferences and the number of trained workers.

Finally, we construct a training investment indicator to analyze the role of decision makers' preferences in shaping firm-level training investments. The investment indicator is, in the absence of worker-level data, calculated as a firm-level average per trained worker. The argument for using the average investment per trained worker (rather than the average per worker on the basis of all employees) is that this measure is best suited for assessing the influence of risk and time preferences on training decisions. The more resources are invested in a trained worker, the higher the sunk costs are if this worker leaves the firm.

For calculating the average training investment per trained worker, we use the direct monetary and time values reported in the survey. The concept of measuring and calculating training investment has been applied in other firm-level surveys, such as the European Continuing Vocational Training Survey (CVTS), and is therefore a standardized method for determining firms' training investments.

The training investment consists of

\footnotetext{
${ }^{6}$ The questions in the survey refer to workers in the occupational group of the last hired worker.
} 
a) the time the trained workers are absent from work in hours $(h)$ multiplied by their hourly wage $(w){ }^{7}$ This measure is referred to as training absence costs $\left(A C=h^{*} w\right)$ and is calculated as the average absence costs per trained worker.

b) the costs for providing an in-house training location, material and internal trainers. This measure is referred to as internal training costs (IC) per trained worker.

c) the costs for traveling, accommodation and course fees, when training takes place outside the firm. This measure is referred to as external training costs $(E C)$ per trained worker.

The average training investment (TC) per trained worker in firm $i$ is thus given by

$$
T C_{i}=A C_{i}+I C_{i}+E C_{i}
$$

\subsection{Variables: Risk and time preferences}

In this paper, we simultaneously analyze the influence of risk attitudes and time preferences. The reason is that there could be a strong relation between both constructs. Even though they are not the same from the conceptual perspective, empirically they nearly always come as twins. All rewards in the future are associated with some risk that they will not be obtained and all risky rewards are in the future (Borghans et al., 2008).

The risk attitude is surveyed in the form of a direct assessment, i.e. the respondents report their willingness to take risks on a scale from 0 to 10 . The exact wording of the question is as follows:

Question 1: "How do you view yourself: Are you a risk taker in general or do you tend to avoid risks? Please indicate your answers on a scale from 0 to 10 , where 0 means you are 'completely unwilling to take risks' and 10 means you are 'very willing to take risks'."

The respective survey question correlates with actual behavior, such as smoking, occupational choices, participation in sports, and many others (Dohmen et al., 2011), and has been identified as the most valid form of measuring risk attitudes in experimental settings (Falk et al., 2013).

Our measurement of time preference relies on two different concepts. The first concept involves the intertemporal trade-off in a rather neutral way. The survey question addresses discounting and measures the individual's preference for giving up consumption today for profits in the future. The second concept captures the hyperbolic discounting, i.e. the fact that individuals tend to weigh the present disproportionately high. In order to capture the concept of hyperbolic discounting we include a question on procrastination, as discussed in the literature. In answering the survey question, respondents report their tendency to delay action although it

\footnotetext{
${ }^{7}$ We use the average skilled worker wage in the firm as a proxy for the wage of a worker in a specific occupation.
} 
would be better to solve the issue immediately. The exact wording of the two questions is as follows:

Question 2: "With regards to financial decisions, how willing are you to give up something that is beneficial for you today in order to benefit more from that in the future? Please use a scale from 0 to 10 , where 0 means 'not willing at all to give up' and 10 means 'very willing to give up'."

Question 3: "To which degree does the following statement apply to you? I tend to postpone things even though it would be better to get them done right away. Please use a scale from 0 to 10 , where 0 means 'does not apply at all' and 10 means 'applies completely'."

Falk et al. (2013) show that the questions correlate with the corresponding intertemporal behavior in experiments. More concretely, the questions correlate in a regression model with the discount rate measured in experiments (i.e. the average switching point with the amount of money today and an amount of money in 12 months). Another study uses an index of the first time-preference question combined with a quantitative time-preference measure and finds that this index also correlates strongly with patient behavior, like saving behavior and educational attainment (Falk et al., 2015). In general, all questions appear to reflect the variation in preferences well, as the whole range of answer possibilities is used.

Even though a survey is often an artificial situation without real incentives, we decided on this type of measurement for various reasons. First, conducting experiments on such a large scale is often not possible. Second, elicitation in a survey allows us to relate the preferences to many other characteristics, as in our case the training investments of the firm. To the best of our knowledge, the BIBB CBS 2012/2013 is the only large-scale survey so far that contains information on both decision makers' economic preferences and firms' training costs. In the survey, we employed questions that show an internal and external validity, i.e. questions that have been shown to relate to both experiment and real-life behavior.

\subsection{Variables: Controls}

Apart from our main independent variables, i.e. the preferences of decision makers in the firms, we include a large set of control variables in the regression models. On the individual level, we include the function of the respondent in the firm. This variable has 9 categories, spanning from owner or CEO to different management functions of the decision maker in the firm. We further control for whether the decision maker is autonomous in making the decision or whether other persons in the firm are involved in the decision-making process. ${ }^{8}$

\footnotetext{
${ }^{8}$ Although the question about the autonomy of decision making refers to the training of apprentices and not explicitly to the training of already qualified workers, we assume a strong correlation between the two decision making subjects, especially when simultaneously controlling for the function of the decision maker in the regressions. The wording of the question is: „To what extend can you decide personally, if and how many trainees are trained in the
} 
On the firm level, we control for the firm's age, presence of institutions (works council and collective bargaining coverage) and the managers' wages. The aim of including such variables in the regression is that they could be correlated with both the decision makers' preferences and the firms' training investment. By including institutions (as signals for better working conditions) and wages of managers in the regressions, potential issues of selection of decision makers into certain firms are addressed. ${ }^{9}$ Furthermore, we control for the firm's qualification structure and whether the firm trains apprentices. In the regression models, we also include the level of capacity utilization as an indicator for the economic situation of the firm, which could be correlated with both the decision maker's risk attitude and the potential or need to invest in worker training.

Finally, we add a set of structural dummy variables including firm size (4), sector (12), state (16) and the occupation of workers (34) to the regression models. These controls aim to reduce firm heterogeneity in the models that might drive training provision and the hiring of decision makers with specific preferences (e.g. in sectors with dynamic growth). For the main model regressing training investment on decision makers' preferences, the (log) number of training participants is added to assess whether (dis)economies of scale exist in training several workers in a given period.

\section{Estimation strategy, results and robustness tests}

This section describes the estimation strategy and the results of our empirical analysis. It further provides robustness test and discusses the limitations of the data.

\subsection{Estimation strategy}

The main question analyzed in this paper is, whether firm-level investment in human capital (training of skilled workers) is contingent on the individual preferences of the decision maker. However, in the following analysis, we extend the scope and also focus on questions related to the mere likelihood $(T P)$ and number of trained workers $(T N)$ in the firm.

Therefore, in a first step, we analyze whether risk attitudes (risk) and time preferences (i.e. procrastination (proc) and the preference for future profits (disc)) of decision makers relate to the training participation of the firm. For this purpose, we use a probit regression with Training $=y e s / n o$ as the dependent variable and our preference measures on the individual level as the main independent variables.

Thus, the first equation to be estimated is

firm? Answers are: 1) "I decide on my own", 2) "I decide together with others", and 3) "I am not involved in the decision".

${ }^{9}$ A further reason for including wages of decision makers in the regressions is the potential link between managerial compensation and risk-taking, which has been discussed in the literature (e.g. Coles et al., 2006). 


$$
T P_{i}=\alpha+\beta_{1} \operatorname{risk}_{D m}+\beta_{2} \operatorname{proc}_{D m}+\beta_{3} \operatorname{disc}_{D m}+\beta_{4} X_{D m}+\beta_{5} X_{i}+\varepsilon_{i},
$$

where $X_{D m}$ is a set of individual-level variables and $X_{i}$ a set of firm-level variables, as described above.

In a second step, we regress the number of trained workers $T N$ in the firm on our preference measures, using a count data framework (negative binomial regressions) with $T N$ as the dependent variable. The choice for a negative binomial regression instead of a Poisson regression model is based on the observation of overdispersion in the count measure. In this framework, the (potential) number of trained workers is strongly related to the size of the firm. Therefore, we use firm size (total number of workers in the firm) as the exposure variable. ${ }^{10} \mathrm{We}$ estimate

$$
\operatorname{logTN}_{i}=\alpha+\beta_{1} \operatorname{risk}_{D m}+\beta_{2} \operatorname{proc}_{D m}+\beta_{3} \operatorname{disc}_{D m}+\beta_{4} X_{D m}+\beta_{5} X_{i}+\varepsilon_{i} .
$$

Transforming the equation yields

$$
T N_{i}=\exp (\alpha) \cdot \exp \left(\beta_{1} \text { risk }_{D m}+\beta_{2} \text { proc }_{D m}+\beta_{3} \operatorname{disc}_{D m}+\beta_{4} X_{D m}+\beta_{5} X_{i}+\varepsilon_{i}\right) .
$$

In the third and last step, we use the (logarithm of) training investment per trained worker $\log (T C)$ as an outcome variable in an OLS regression to determine the role of decision makers preferences for firms' investment behavior:

$$
\log (T C)_{i}=\alpha+\beta_{1} \operatorname{risk}_{D m}+\beta_{2} \operatorname{proc}_{D m}+\beta_{3} \operatorname{disc}_{D m}+\beta_{4} X_{D m}+\beta_{5} X_{i}+\varepsilon_{i} .
$$

\subsection{Results: Description of the main variables}

This section of the paper first provides descriptive information on both the main independent and the main dependent variables. It then provides regression results and discusses their robustness and limitations.

Starting with the decision makers' preferences, Figure 2 provides the distributions of risk attitudes and time preferences. While the willingness to take risks is close to normally distributed with a median of 5 , the distribution of procrastination is skewed to the left with a median of 2. Finally, the distribution of preferring future profits is skewed to the right with a median of 7. The three preference measures are only marginally correlated, with correlation coefficients between 0.028 and 0.089 .

\footnotetext{
${ }^{10}$ See Cameron and Trivedi (2013) for a discussion on count data analysis and the implementation of exposure variables in the regression models.
} 
Figure 2: Distribution of the individual preferences of decision makers

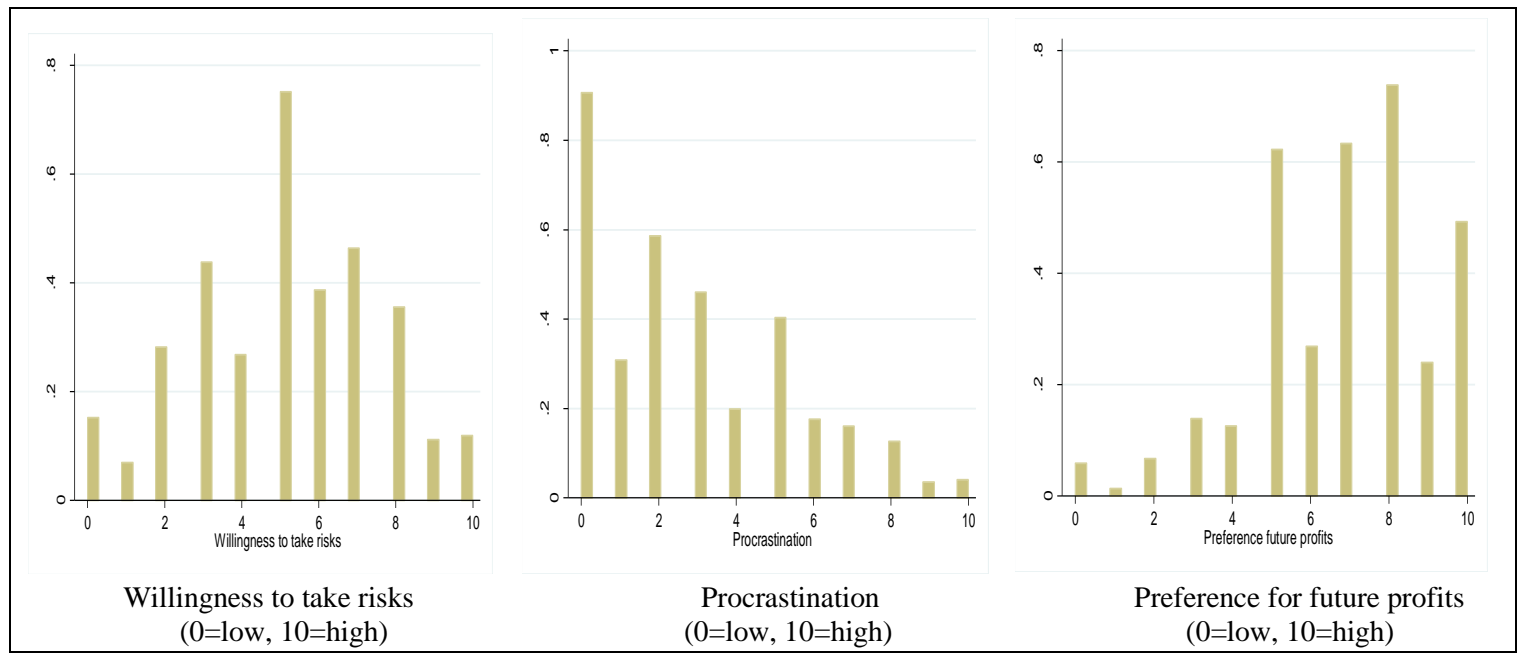

Source: BIBB CBS 2012/2013

Table A1 in the appendix provides descriptive information about the main dependent variables of training provision, the number of trained workers and the training investment per trained worker. 64 percent of the firms provide training to at least one worker, with an average training duration of 36 hours per trained worker. The average number of workers trained is 2.54 across all firms (i.e. including the zeros of non-training firms), and firms spend close to $€ 1,200$ per worker trained. The majority of the training investments are external training costs $(E C)$ with a mean of $€ 576$ and absence costs $(A C)$ with a mean of $€ 482$. Internal training costs $(I C)$, on the contrary, make up for only 12 percent of the total investment ( $€$ 137). Figure A1 provides a graphical display of the distribution of training investment per trained worker. Descriptive information about the individual-level and firm-level independent variables used in the regression models are given in Table A2.

In the following section, we first discuss the results referring to the relationship between decision makers' preferences and training participation and the number of workers trained in the firm. We then turn to the results from regressing the training investment per trained worker on decision makers' preferences. In the respective tables, we provide results for three different models, with Model (i) being the baseline model, Model (ii) being the baseline model plus the set of individual-level variables $X_{D m}$ and finally with Model (iii) adding firm-level controls $X_{i}$ to Model (ii).

\subsection{Results: Regression analysis}

Table A3 in the appendix shows the results from regressing our first dependent variable (training participation) on the preferences of decision makers in firms. The table provides results 
for the baseline regression (Model (i)), the baseline regression plus additional individual variables (Model (ii)) and the full model (Model (iii)) that also includes firm-level variables.

The regression results imply no statistically significant relation between the risk attitude and firms' training participation. Likewise, the coefficients of procrastination are insignificant in all three models. However, the coefficient of decision makers' preference for future profits is positive and significant at the 5-percent level in the full model, indicating that firms with a future-oriented decision maker are more likely to provide training to their workers.

With respect to the set of control variables, the function in the firm plays an important role for the training participation. If CEOs and heads of departments are deciding on training participation, firms are more likely to participate than if the owner of the firm takes the decision. In addition, the (average) wage on the manager level is positively correlated with the likelihood of providing training to the workers.

Similar to the regression results in Table A3, the negative binomial regression results in Table A4 suggest that decision makers' preference for future profits increases the training involvement of firms. The respective coefficient is positive and statistically significant at the 10-percent level, indicating that more workers are trained in firms, in which the decision maker prefers future profits over current consumption. Again, coefficients on risk attitude and procrastination show the expected sign (i.e. positive and negative, respectively), but are not significantly different from zero. ${ }^{11}$

Table 1 provides results from the OLS regressions that include training investment per trained worker in the firm as the dependent variable. These results differ from the previous regressions in that they suggest risk attitudes and procrastination of decision makers to be relevant factors in determining firm-level training investments. Concerning risk attitudes, the coefficient remains large and significant throughout the three different models (Model (i) to Model (iii)). According to Model (iii) in the table, an increase of the risk preference of one unit increases firms' training investments by 5.5 percent.

With respect to procrastination, we find a negative and significant (at the 5-percent level) relationship, which is in line with our expectations as formulated in Hypothesis 2: Firms with decision makers showing higher levels of procrastination invest less in their workers' training. The coefficient implies that an increase in one unit of procrastination reduces training investments by 3.7 percent. $^{12}$

In comparison to the previous regressions on training participation and the number of workers trained, the decision makers' preference for future profits is statistically not related to

\footnotetext{
${ }^{11}$ Note that the $\ln$ (alpha) in Model (iii) is significant, which supports the choice of a negative binomial regression model instead of a Poisson regression model.

${ }^{12}$ The change from an insignificant to a significant coefficient of procrastination from Model (ii) to Model (iii) is mainly driven by the inclusion of the institutional variables (works councils and collective bargaining) and the inclusion of occupational controls.
} 
the training investment of the firm. This result does not lend support to Hypothesis 3 , which proposes a positive relationship between the decision makers' preference for future profits and the training investment of the firm.

Table 1: Training investment and decision makers' preferences

\begin{tabular}{|c|c|c|c|}
\hline \multicolumn{4}{|c|}{ Dependent variable: (Ln) Training investments per trained worker } \\
\hline & Model (i): baseline & Model (ii): (i) $+X_{D m}$ & Model (iii): (ii) $+X_{i}$ \\
\hline \multirow[t]{2}{*}{ Willingness to take risks } & $0.061^{* * * * *}$ & $0.063^{* * * 3 \%}$ & 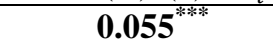 \\
\hline & $(\mathbf{0 . 0 2 3 )}$ & $(\mathbf{0 . 0 2 3})$ & $(0.017)$ \\
\hline \multirow[t]{2}{*}{ Procrastination } & -0.028 & -0.021 & $-0.037^{* *}$ \\
\hline & $(0.021)$ & $(\mathbf{0 . 0 2 1})$ & $(0.018)$ \\
\hline \multirow[t]{2}{*}{ Preference for future profits } & -0.028 & -0.034 & -0.028 \\
\hline & $(0.029)$ & $(\mathbf{0 . 0 2 9})$ & $(\mathbf{0 . 0 2 2})$ \\
\hline \multicolumn{4}{|l|}{ Reference: Owner/partner of firm } \\
\hline \multirow[t]{2}{*}{ Interviewed person: CEO } & & $0.304^{* *}$ & $0.330^{* *}$ \\
\hline & & $(0.132)$ & $(0.139)$ \\
\hline \multirow[t]{2}{*}{ Interviewed: Head of department } & & 0.306 & $0.333^{*}$ \\
\hline & & $(0.207)$ & $(0.175)$ \\
\hline \multirow[t]{2}{*}{ Interviewed: Head of HRM } & & $0.578^{* *}$ & 0.166 \\
\hline & & $(0.238)$ & $(0.214)$ \\
\hline \multirow[t]{2}{*}{ Interviewed: Head of HR } & & $1.020^{* * * *}$ & $0.693^{* *}$ \\
\hline & & $(0.240)$ & $(0.296)$ \\
\hline \multirow[t]{2}{*}{ Interviewed: Business admin. } & & -0.229 & -0.100 \\
\hline & & $(0.376)$ & $(0.362)$ \\
\hline \multirow[t]{2}{*}{ Interviewed: Technical manager } & & $0.815^{* * * *}$ & $0.558^{* *}$ \\
\hline & & $(0.145)$ & $(0.227)$ \\
\hline \multirow[t]{2}{*}{ Interviewed: Training manager } & & $0.611^{* * * *}$ & $0.624^{*}$ \\
\hline & & $(0.198)$ & $(0.319)$ \\
\hline \multirow{2}{*}{ Interviewed: Other function in firm } & & -0.037 & -0.251 \\
\hline & & $(0.195)$ & $(0.179)$ \\
\hline \multirow[t]{2}{*}{ Only decision maker } & & 0.110 & $0.171^{*}$ \\
\hline & & $(0.125)$ & $(0.102)$ \\
\hline \multirow[t]{2}{*}{ Firm older than 20 years } & & & -0.147 \\
\hline & & & $(0.095)$ \\
\hline \multirow{2}{*}{ Wage on management level (in $€$ ) } & & & 0.000 \\
\hline & & & $(0.000)$ \\
\hline \multirow[t]{2}{*}{ Works council in firms } & & & 0.120 \\
\hline & & & $(0.145)$ \\
\hline \multirow[t]{2}{*}{ Covered by collective bargaining } & & & -0.026 \\
\hline & & & $(0.098)$ \\
\hline \multirow[t]{2}{*}{ Firm trains apprentices } & & & -0.026 \\
\hline & & & $(0.076)$ \\
\hline \multirow[t]{2}{*}{ Utilized capacity of firm: Fully used } & & & -0.004 \\
\hline & & & $(0.099)$ \\
\hline \multirow[t]{2}{*}{ Number of workers trained (ln) } & & & -0.047 \\
\hline & & & $(0.067)$ \\
\hline Qualification structure controls & No & No & Yes \\
\hline Firm size controls & No & No & Yes \\
\hline Economic sector controls & No & No & Yes \\
\hline Occupation controls & No & No & Yes \\
\hline Regional controls & No & No & Yes \\
\hline Constant & $6.632 * * *$ & $6.461 * * *$ & $6.061 * * *$ \\
\hline & $(0.211)$ & $(0.229)$ & $(0.428)$ \\
\hline $\mathrm{R} 2$ & 0.030 & 0.070 & 0.339 \\
\hline Observations & 1768 & 1768 & 1768 \\
\hline
\end{tabular}


Taken together, the differences in the results in our two time-preference measures suggest that hyperbolic discounting (as measured by procrastination) is a relevant determinant for training investments, while the linear discounting is relevant for the training decision and number of trained workers. These findings confirm that the underlying mechanisms should be modeled separately instead of using merely one of the time preferences available in the survey.

Concerning the other independent variables in the regressions, we find no direct evidence for economies or diseconomies of scale, as the $(\log )$ of the number of trained workers is not significantly related to training investments. Table 1 further shows that the function of the decision maker in the firm relates significantly to the firm's investment in training. Being a CEO or the head of department increases the training investment as compared to being the owner/partner of a firm. In addition, making decisions alone or together with other colleagues in the firm appears to play a role.

Because both the function in the firm and the autonomy of decision making could be correlated with the preferences measured in the survey, we address this and other issues in the following section.

\subsection{Robustness and limitations}

In this section, we undertake several adjustments to our main regression specifications in order to test for the robustness of the results. We then discuss the data limitations of the study.

\subsubsection{Robustness}

Concerning the robustness of results, we provide a set of additional estimates. First, as implied by the regression results in Table 1, the function and the autonomy of decision making seem to have an independent influence on the training investment. To test whether our results hold when focusing on only those decision makers that hold key functions in the firm, we restrict the sample to different groups of decision makers. Column 1 in Table A5 provides estimates for the owners/partners of the firm. The regression in Column 2 additionally includes senior managers (CEOs and heads of departments) in the sample and Column 3 further restricts the sample to fully autonomous decision makers, i.e. decision makers taking the decision independently from other people in the firm. All three regressions largely confirm the relevance of risk attitudes and procrastination for firm-level training investments, albeit at a varying significance levels and with coefficient sizes between 0.37 and 0.52 .

Second, we take a closer look at the different subcomponents of training investments in order to test, whether the relation between decision makers' preferences and firms' training investment is driven by certain components of the indicator. We therefore regress the subcomponents from equation (6), i.e. absence costs (AC), internal costs $(I C)$ and external costs 
$(E C)$ on the decision makers' preferences. We further provide estimates for the training hours per trained worker $(h)$ as a non-monetary outcome. We run Tobit regressions with the untransformed components as dependent variables to take into account the varying number of zero observations in those variables. The results in Table A6 in the appendix suggest that the willingness to take risks is positively related to all three of the investment components and the number of training hours per trained worker. For procrastination, the (negative) relation is particularly strong for absence costs and the average training hours per worker.

Third, we acknowledge the lack of individual-level socio-demographic characteristics in our survey data. The literature in the field suggests that gender and age are correlated with the willingness to take risks (e.g. Filippin and Crosetto, 2016 or Dohmen et al., 2011). Moreover, procrastination appears to decrease with age but does not necessarily differ between men and women (Beutel et al., 2016). Time preferences (here: the value of future options) appear to be positively related to age and being male (Bishai, 2004).

The problem arising from the lack of individual-level variables in the data is that these could be correlated with both the respective preference as measured in the survey and the training investment in the firm. As an example, older managers or owners of a firm could have a lower willingness to take risks, and at the same time view training as a lower priority relative to younger decision makers, because training primarily pays off in the long run, possibly past their retirement. With the age control lacking in the regression, we would observe a positive correlation between the willingness to take risks and firms' training investment. Yet, this relation would exist due to omitting the age control rather than due to a true causal relationship.

However, we expect the subgroup of decision makers (i.e. mostly owners/partners and managers) to be more homogeneous in their socio-demographic characteristics than the total population of labor market participants. Caliendo et al. (2009) show that risk attitudes differ by gender in the total population and, at the same time, are significant predictors for entrepreneurship. The authors follow that these combined results explain the lower share of female entrepreneurs. In other words, male and female entrepreneurs are likely to be more similar with respect to their risk attitudes than the male and female working population as a whole.

To offer an additional treatment for this problem, we identify economic sectors in which the gender of managers is relatively homogeneous. The data used for the identification of these sectors is the German Mikrozensus of the year 2012. Using this data, we use the group of managers (ISCO-group 1) to aggregate the socio-demographic characteristics on the sector level. Selecting sectors with a quota of male managers above $70 \%$, we run the same regression as displayed in Table 1. With respect to training participation and number of trained workers, the results presented in Table A7 are in line with those for the full sample (Tables A3 and A4). 
Further, the relation between decision makers' risk attitudes and firms' training investment remains robust, whereas the coefficient on procrastination turns insignificant when using the restricted sample. Despite the latter deviation from the full-sample results, the focus on sectors with mainly male decision makers does not suggest that omitting socio-demographic variables in the regressions alters the observed relation between individual preferences and firms' training behavior. $^{13}$

Fourth, we recognize the vast amount of studies discussing the general or specific contents of worker training and propose a robustness analysis to address this issue. Investment in general training from the firm's perspective is more risky than firm-specific training, because the former can be used in other firms in addition to the training firm (Becker, 1962). Assuming that firms investing in general worker training need to recover the costs by paying a wage below (the increased) productivity, workers have incentives to change the employer to obtain a wage corresponding to their productivity. Following our initial argument that worker training is risky for the firm, it should even be more risky when firms finance general training. For our study, this leads to the question of whether the relation between decision makers' risk attitudes and time preferences persists, when we only focus on general training investments. ${ }^{14}$ Although we cannot precisely distinguish between general and firm-specific training in our data, we run separate regressions for firms that exclusively invest in external training. Our argument is that external training courses are more likely to contain general knowledge and skills than internal courses, because it is usually certified and standardized. Table A8 provides the results for firms financing only external training. The respective coefficient for the willingness to take risks is slightly smaller (and significant at the 5-percent level), while the coefficient for procrastination is slightly larger. Overall, the results of the alternative specification confirm those obtained from our main regression, as shown in Table $1 .^{15}$

Fifth, we test for heterogeneity in the relation between preferences and training investments across the training investment dimension. We run quantile regressions and plot the outcome in four different figures (intercept and the three preference measures), as shown in Figure A2. Overall, we do not find evidence for effect heterogeneity based on this test.

Finally, we test for interaction effects in our regression, including the interaction terms of each pair of preferences (three interaction variables) and one interaction of all three preferences in the model that is given in Table 1 . The regression results indicate that none of the included interaction terms is significantly different from zero, which suggests that the three preferences

\footnotetext{
${ }^{13}$ We tested a similar approach for the age dimension. However, mean and variance in the respective economic sectors were very similar, so that a "more" homogeneous sub-sample could not be created.

${ }^{14}$ We define general training as knowledge and skills that are transferable to other firms. This also includes occupation-specific knowledge and skills.

${ }^{15}$ The regression using firms with only internal or internal and external training yields a risk coefficient of about the same size as in the case of using firms with only external training. However, this coefficient is not significant.
} 
do not reinforce each other in their relation with training investments. ${ }^{16}$ Overall, our robustness analysis above generally supports the results obtained from our main regressions.

\subsubsection{Limitations}

Although we can draw on unique survey information about decision makers' preferences, we need to address the potential limitations of the data. One of these limitations is that the questions concerning both the firms' training activity and the decision makers' preferences are reported by the same person in the same interview. In our case, the decision maker first reports, among others, the training participation, the number of trained workers and the training investment in the firm, and later answers questions about his/her preferences. A common method bias could arise, if the decision maker's answers on the preference questions are correlated with the answers given on the firm's training activities earlier in the interview. For our results to hold, we need to assume that there is no systematic relationship between the two sets of answers. Although we cannot fully rule out the possible existence of a common method bias, we argue that the long multi-purpose questionnaire prior to the preference questions touches upon a multitude of firm-related topics and that, at the point of answering the preference questions at the end of the survey, a direct cognitive connection to the firm's worker training topic seems unlikely. Further, at least in the case of risk attitudes, we cannot speculate about the direction of the potential bias on the basis of the literature in the field.

Another potential issue could be the existence of endogeneity in the form of reversed causality or missing variables correlated with both preferences and training investments. In our case, reverse causality would be an issue if a firm's investment in training influences the decision maker's preferences rather than the other way around. Without being able to test for reverse causality ourselves, we find mixed evidence with respect to the stability of risk or time preferences in the literature. ${ }^{17}$ Furthermore, the issue of reverse causality is discussed in several studies, providing little evidence for its existence for outcomes such as occupational choice (Bonin et al., 2007), migration (Jaeger et al., 2010) or self-employment (Ekelund et al., 2005).

A missing variable bias could emerge, e.g. if a firm has a governing board that appoints the manager and at the same time determines the budget for training. In this case, the existence of a governance board would need to enter the regression as a control variable to yield unbiased results. Although we have no direct information about the governance structure in the firm, a possible bias would occur only for those firms, where managers are dependent on a board.

\footnotetext{
${ }^{16}$ The results are not shown in the paper but are available upon request.

${ }^{17}$ While Acosta (2015), Meier and Sprenger (2015) or Andersen et al. (2008b) find a relative stability of risk or time preferences, Chuang and Schechter (2015) find stable preferences in panel survey data, but a large instability in experimental settings. Brachert and Hill (2014) find changing risk attitudes for respondents becoming self-employed.
} 
However, Table A5 shows that our estimates are robust when selecting on the owners/partners in the firm, which usually are not restricted by governing boards.

Given the potential limitations imposed by the data, we refrain from interpreting our results as purely causal. Notwithstanding, this paper provides empirical findings that, contingent on our assumptions, lead to implications that are discussed in the final section of the paper.

\section{Implications}

This paper analyzed the link between decision makers' individual preferences and firms' investment behavior. Building on a simple profit-maximization model, we developed a set of hypotheses and tested these using firm-level survey data. Focusing on human capital investment in worker training as an example for "risky" investments, we find that a higher willingness to take risks of the decision maker is associated with a higher training investment of the firm. Furthermore, results provide support for the expected negative relationship between a decision maker's level of procrastination (as a hyperbolic time preference) and a firm's investment in training. A higher preference for future profits is, on the contrary, not significantly related to training investments, but rather to the provision and number of workers trained. These empirical findings are robust to several alternative specifications.

The results of this paper have implications with respect to research, policy and practice. First, decision makers' preferences have rarely been discussed in those areas of the training literature that address the question of why certain firms invest in training that is transferable across firms (i.e. in "general" training) while others do not. Until now, especially institutional factors (e.g. minimum wages, collective bargaining, employment protection) and labor market conditions (e.g. monopsony, mobility, poaching or wage structures) have been identified as strong determinants for training investments. Person-level preferences of decision makers as an explanation for firms' training engagement have so far received little attention. Further studies should therefore shed light on the question of whether the observed differences in firms' human capital investments within and across countries are (at least partly) driven by differences in the preferences of their decision makers. The question arises if changes in the risk attitudes and time preferences of decision maker cohorts could contribute to the observed increase in the provision of worker training in firms (Dummert and Leber, 2016).

Second, from a policy perspective, the established link between preferences and firm investment would offer some scope for measures aiming to increase firms' commitment to invest in the human capital of their workers. In the face of risk aversion and a present bias of decision makers, there could be an issue of underinvestment in worker training from a macrolevel perspective. Although we cannot directly test for underinvestment due to the lack of information on the optimal training investments, the theoretical model in this paper implies that 
risk aversion and present bias would lead to an underinvestment in training when assuming perfect information. Upon confirmation of the results presented in this paper by other studies, the introduction of measures such as training funds or payback clauses could be discussed anew.

Third, from the single firm's perspective, our model and the empirical analysis suggest that the realized training investment of a firm could be suboptimal depending on the specific preferences of the decision maker. Firms could think about organizational mechanisms of how to correct for potential preference-effects in training investment decisions. For example, literature has shown that managers' risk-taking behavior varied across and within different forms of monitoring systems (Wiseman and Gomez-Mejia, 1998). This observation implies that effective monitoring mechanisms could be one approach to tackle potential biases in decision making. Furthermore, March and Shapira (1987) discuss the prospects for changing managerial perspectives on the firm's risk-taking through direct training. Such training could aim at neutralizing the possible link between personal preferences and firm-level decisions. Finally, more emphasis could be put on the testing and evaluating of personal preferences in the recruitment of managers with the aim to ensure an alignment of the personal attitudes of decision makers and the firm's general market or investment strategies. 


\section{Literature}

Acosta, N. S. (2015). Economic Preferences and Financial Risk Taking. (Doctoral dissertation, Maastricht University).

Andersen, S., Harrison, G. W., Lau, M. I., \& Rutström, E. E. (2008a). Eliciting risk and time preferences. Econometrica, 76(3), 583-618.

Andersen, S., Harrison, G. W., Lau, M. I., \& Rutström, E. E. (2008b). Lost in state space: are preferences stable? International Economic Review, 49(3), 1091-1112.

Armstrong, M., \& Huck, S. (2010). Behavioral Economics as Applied to Firms: A Primer. Competition Policy International, 6(1), 3-45.

Becker, G. S. (1962). Investment in Human Capital: A Theoretical Analysis. Journal of Political Economy, 70(5), 9-49.

Benhabib, J., Bisina, A., \& Schottera, A. (2009). Present-bias, quasi-hyperbolic discounting, and fixed costs. Games and Economic Behavior, 69(2), 205-223.

Bernile G., Bhagwat V. \& Rau P.R. (2017). What Doesn't Kill You Will Only Make You More Risk-Loving: Early-Life Disasters and CEO Behavior. Journal of Finance, 72(1), 167206.

Bertrand, M., \& Schoar, A. (2003). Managing with Style: The Effect of Managers on Firm Policies. Quarterly Journal of Economics, 118(4), 1169-1208.

Beutel, M. E., Klein, M., Aufenanger, S., Brähler, E., Dreier, M., Müller, K. W., \& Wölfling, K. (2016). Procrastination, Distress and Life Satisfaction across the Age Range - A German Representative Community Study. PloS one, 11(2), e0148054.

Bishai, D. M. (2004). Does Time Preference Change with Age? Journal of Population Economics, 17(4), 583-602.

Bonin, H., Dohmen, T., Falk, A., Huffman, D., \& Sunde, U. (2007). Cross-sectional Earnings Risk and Occupational Sorting: The Role of Risk Attitudes. Labour Economics, 14(6), 926-937.

Borghans, L., Duckworth, A. L., Heckman, J. J., \& ter Weel, B. (2008). The Economics and Psychology of Personality Traits. Journal of Human Resources, 43(4), 972-1059.

Borjas, G. J. (2008). Labor Economics. New York: McGraw-Hill Education.

Brachert, M., \& Hyll, W. (2014). On the Stability of Preferences: Repercussions of Entrepreneurship on Risk Attitudes. SOEP papers on Multidisciplinary Panel Data Research.

Brown, S., Ortiz, A., \& Taylor, K. (2006). Educational Attainment and Risk Preference. Sheffield Economic Research Paper Series. Department of Economics. The University of Sheffield.

Caliendo, M., Fossen, F., \& Kritikos, A. S. (2009). Risk attitudes of nascent entrepreneurs - new evidence from an experimentally validated survey. Small Business Economics, 32(2), 153-167.

Caliendo, M., Fossen, F., \& Kritikos, A. S. (2014). Personality characteristics and the decisions to become and stay self-employed. Small Business Economics, 42(4), 787-814.

Camerer, C. F., \& Loewenstein, G. (2004). Behavioral Economics: Past, Present, Future. In C. F. Camerer, G. Loewenstein and M. Rabin (Eds.), Advances in Behavioral Economics (pp. 3-51). New Jersey: Princeton University Press.

Cameron, A. C., \& Trivedi, P. K. (2013). Regression Analysis of count data. Cambridge university press.

Chuang, Y., \& Schechter, L. (2015). Stability of experimental and survey measures of risk, time, and social preferences: A review and some new results. Journal of Development Economics, 117, 151-170.

Coles, J. L., Naveen, D. D., \& Naveen, L. (2006). Managerial incentives and risk-taking. Journal of Financial Economics, 79, 431-468.

Cucculelli M. \& Ermini B. (2013). Risk attitude, product innovation, and firm growth. Evidence from Italian manufacturing firms. Economics Letters, 118(2), 275-279. 
De Grip, A., \& Sauermann, J. (2012). The effects of training on own and co-worker productivity: Evidence from a field experiment. Economic Journal, 122(560), 376-399.

Dohmen, T., Falk, A., Huffman, D., \& Sunde, U. (2009). Homo Reciprocans: Survey Evidence on Behavioral Outcomes. Economic Journal, 119(536), 592-612.

Dohmen, T., Falk, A., Huffman, D., Sunde, U., Schupp, J., \& Wagner, G. G. (2011). Individual risk attitudes: Measurement, determinants, and behavioral consequences. Journal of the European Economic Association, 9(3), 522-550.

Dummert, S., \& Leber, U. (2016). Betriebliche Weiterbildung. In Bundesinstitut für Berufsbildung (Ed.), Datenreport zum Berufsbildungsbericht 2016 (pp. 214-218). Bonn.

Ekelund, J., Johansson, E., Järvelin, M. R., \& Lichtermann, D. (2005). Self-employment and risk aversion - evidence from psychological test data. Labour Economics, 12(5), 649659.

Falk, A., Becker, A., Dohmen, T., Enke, B., Sunde, U., \& Huffman, D. (2015). The Nature of Human Preferences: Global Evidence. Paper presented at the CESifo Area Conference on Behavioral Economics, Munich, Germany.

Falk, A., Becker, A., Dohmen, T., Huffman, D., \& Sunde, U. (2013). An Experimentally Validated Preference Survey Module. University of Bonn, Germany.

Filippin, A., \& Crosetto, P. (2016). A reconsideration of gender differences in risk attitudes. Management Science 62(11), 3138-3160.

Fouarge, D., Kriechel, B., \& Dohmen, T. (2014). Occupational Sorting of School Graduates: The Role of Economic Preferences. Journal of Economic Behavior \& Organization, 106, 335-351.

Fouarge, D., Schils, T., \& de Grip, A. (2013). Why do low-educated workers invest less in further training? Applied Economics, 45, 2587-2601.

Frederick, S., Loewenstein, G., \& O'Donoghue, T. (2002). Time discounting and time preference: A critical review. Journal of Economic Literature, 40(2), 351-401.

Golsteyn, B., Grönqvist, H. \& Lindahl, L. (2014). Adolescent Time Preferences Predict Lifetime Outcomes. Economic Journal, 124(580), F739-F761.

Graham J.R., Harvey C.R., \& Puri M. (2013). Managerial attitudes and corporate actions. Journal of Financial Economics, 109(1), 103-121.

Green, L., \& Myerson, J. (2004). A discounting framework for choice with delayed and probabilistic rewards. Psychological Bulletin, 130(5), 769-792.

Guiso, L., \& Paiella, M. (2008). Risk Aversion, Wealth and Background Risk. Journal of the European Economic Association, 6(6), 1109-1150.

Hambrick, D. C., \& Mason, P. (1984). Upper Echelons: The Organization as a Reflection of its Top Managers. Academy of Management Review, 9(2), 193-206.

Holladay, C. L., \& Quiñones, M. A. (2008). The influence of training focus and trainer characteristics on diversity training effectiveness. Academy of Management Learning \& Education, 7(3), 343-354.

Jaeger, D. A., Dohmen, T., Falk, A., Huffman, D., Sunde, U., \& Bonin, H. (2010). Direct evidence on risk attitudes and migration. Review of Economics and Statistics, 92(3), 684-689.

Jansen, A. (2016). Is investing in apprentices related to decision makers' altruism and their high time preference? Research Memorandum No 010, Research Centre for Education and the Labour Market (ROA).

Kahneman, D., \& Riepe, M. W. (1998). Aspects of Investor Psychology. Journal of Portfolio Management, 24(4), 52-65.

Kapteyn, A., \& Teppa, F. (2011). Subjective Measures of Risk Aversion, Fixed Costs, and Portfolio Choice. Journal of Economic Psychology, 32(4), 564-580.

Kremer, M., Lee, J., Robinson, J., \& Rostapshova, O. (2013). Behavioral Biases and Firm Behavior: Evidence from Kenyan Retail Shops." American Economic Review, 103(3), 362-68.

Leuven, E. (2005). The economics of private sector training: A survey of the literature. Journal of Economic Surveys, 19(1), 91-111. 
Levhari, D., \& Weiss, Y. (1974). The effect of risk on the investment in human capital. American Economic Review, 8(4), 950-963.

March, J. G., \& Shapira, Z. (1987). Managerial Perspectives on Risk and Risk Taking. Management Science, 33(11), 1404-1418.

Meier, S., \& Sprenger, C. D. (2015). Temporal stability of time preferences. Review of Economics and Statistics, 97(2), 273-286.

Muehlemann, S., \& Wolter, S. C. (2011). Firm-sponsored Training and Poaching Externalities in Regional Labor Markets. Regional Science and Urban Economics, 41(6), 560-570.

Pattillo, C., \& Soderbom, M. (2000). Managerial Risk Attitudes and Firm Performance in Ghanaian Manufacturing: an Empirical Analysis based on Experimental Data. CES Working Paper Series 2000-17.

Rashad Abdel-Khalik, A. (2014). CEO risk preference and investing in R \& D. Abacus, 50(3), 245-278.

Reuben, E., Sapienza, P., \& Zingales, L. (2015). Procrastination and impatience. Journal of Behavioral and Experimental Economics, 58, 63-76.

Sabater-Grande, G., \& Georgantzis, N. (2002). Accounting for risk aversion in repeated prisoners' dilemma games: an experimental test. Journal of Economic Behavior \& Organization, 48, 37-50.

Schiel, S., Schröder, H., Eichenlaub, A., Dickmann, C., Gilberg, R., \& Kleudgen, M. (2014). Bericht: Kosten und Nutzen der Ausbildung, Rekrutierung und Weiterbildung von Fachkräften. infas Institut für angewandte Sozialwissenschaft. Bonn.

Skriabikova, O. J., Dohmen, T., \& Kriechel, B. (2014). New evidence on the relationship between risk attitudes and self-employment. Labour Economics, 30, 176-184.

Tanaka, T., Camerer, C. F., \& Nguyen, Q. (2010). Risk and Time Preferences: Linking Experimental and Household Survey Data from Vietnam. American Economic Review, $100(1), 557-571$.

Tanaka, M., \& Sawada, Y. (2015). Risk Preference of Managers and Firm Investments in Lao PDR', in Sawada, Y. and S. Oum (eds.). Disaster Risks, Social Preferences, and Policy Effects: Field Experiments in Selected ASEAN and East Asian Countries', ERIA Research Project Report FY2013, No.34., pp.265-283.

Wang, G., Holmes, R. M., Oh, I.-S., \& Zhu, W. (2016). Do CEOs Matter to Firm Strategic Actions and Firm Performance? A Meta-Analytic Investigation Based on Upper Echelons Theory. Personnel Psychology, 69 775-862.

Wiseman, R. M., \& Gomez-Mejia, L. R. (1998). A Behavioral Agency Model of Managerial Risk Taking. Academy of Management Review, 23(1), 133-153. 


\section{Appendix}

\section{Equations:}

Equations A1: Intermediate steps in deriving the optimal amount of training for a firm

$$
\begin{gathered}
\pi=p_{b} \cdot \frac{1}{(1+r)} \cdot f \cdot t^{\alpha}-t \\
\pi^{\prime}=\alpha \cdot p_{b} \cdot \frac{1}{(1+r)} \cdot f \cdot t^{\alpha-1}-1=0 \\
\alpha \cdot p_{b} \cdot \frac{1}{(1+r)} \cdot f \cdot t^{\alpha-1}=1 \\
t^{\alpha-1}=\frac{(1+r)}{f \alpha \cdot p_{b}} \\
t=\left(\frac{1+r}{f \alpha p_{b}}\right)^{1 /(\alpha-1)} \\
t=\left(\frac{1+r}{f \alpha p_{b}}\right)^{-1 /(1-\alpha)} \\
t^{*}=\left(\frac{f \alpha p_{b}}{1+r}\right)^{1 /(1-\alpha)}
\end{gathered}
$$




\section{Figures:}

Figure A1: Distribution of firms' training investment (in $€$ )

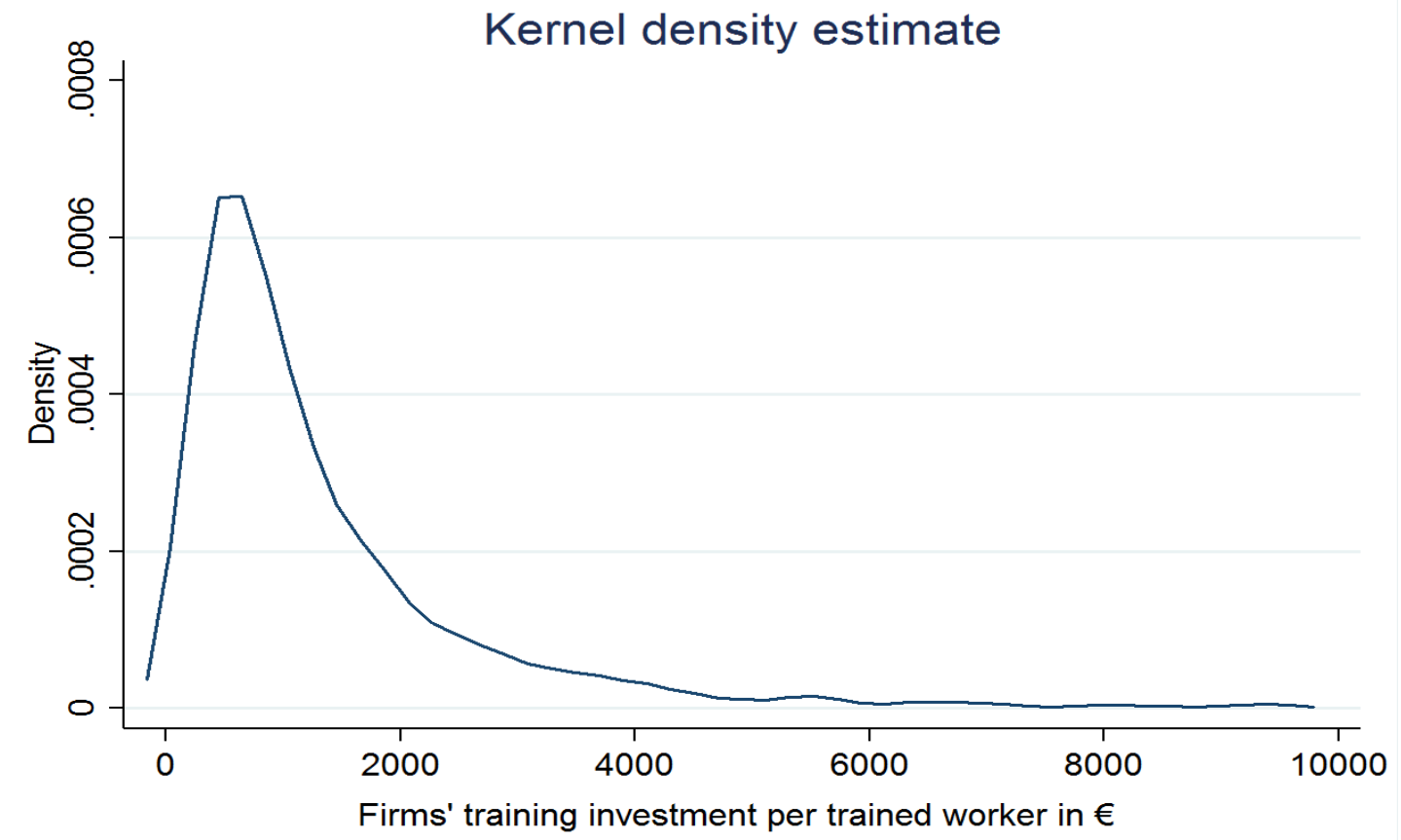

kernel $=$ epanechnikov, bandwidth $=173.3776$

Source: BIBB CBS 2012

Figure A2: Quantile regressions of training investment on decision makers' preferences
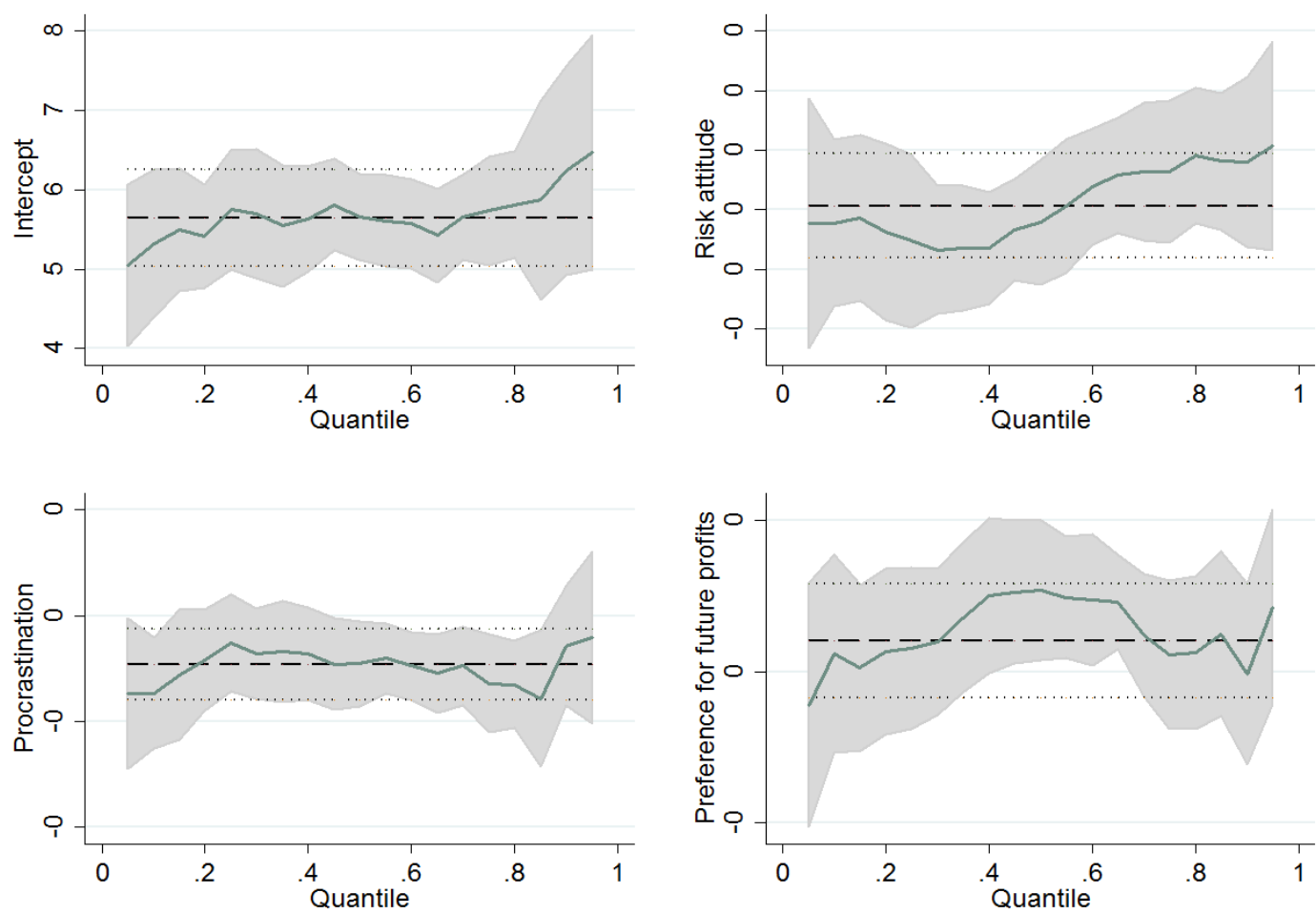

Source: BIBB CBS 2012. 


\section{Tables:}

Table A1: Descriptive information about training-related variables

\begin{tabular}{|l|c|c|c|c|c|}
\hline Variable & Obs & Mean & Std. Dev. & Min & Max \\
\hline \multicolumn{2}{|l|}{} & & \multicolumn{4}{|c|}{$\mid$} \\
\hline Training in firm (yes/no) & 2589 & 0.64 & 0.48 & 0 & 1 \\
\hline Number of trained workers & 2589 & 2.54 & 10.56 & 0 & 1300 \\
\hline Training investment per trained worker in $€$ & 1768 & 1195 & 1334 & 0 & 21486 \\
\hline ...of those: Absence costs (AC) in $€$ & 1768 & 482 & 719 & 0 & 17986 \\
\hline ...of those: External training costs (EC) in $€$ & 1768 & 576 & 772 & 0 & 9500 \\
\hline ...of those: Internal training costs (IC) in $€$ & 1768 & 137 & 356 & 0 & 5500 \\
\hline Training duration (h) in hours & 1768 & 36 & 53 & 0 & 1200 \\
\hline
\end{tabular}

Source: BIBB CBS 2012. 
Table A2: Descriptive information about individual-level and firm-level variables

\begin{tabular}{|c|c|}
\hline Variable & Mean \\
\hline \multicolumn{2}{|l|}{ Individual level } \\
\hline Willingness to take risks & 5.09 \\
\hline Procrastination & 2.83 \\
\hline Preference for future profits & 7.09 \\
\hline Interviewed: Owner/partner of firm & 0.70 \\
\hline Interviewed: CEO & 0.13 \\
\hline Interviewed: Head of department & 0.04 \\
\hline Interviewed: Head of HRM & 0.04 \\
\hline Interviewed: Head of HR development & 0.00 \\
\hline Interviewed: Business admin. manager & 0.01 \\
\hline Interviewed: Technical manager & 0.01 \\
\hline Interviewed: Training manager & 0.01 \\
\hline Interviewed: Other function in firm & 0.04 \\
\hline Only decision maker for training decisions & 0.70 \\
\hline \multicolumn{2}{|l|}{ Firm level - qualification structure, wage } \\
\hline Firm older than 20 years & 0.42 \\
\hline Monthly wage management level (in €) & 3367 \\
\hline Works council in firms & 0.04 \\
\hline Covered by collective bargaining & 0.34 \\
\hline Firm trains apprentices & 0.25 \\
\hline Utilized capacity of firm: Fully used & 0.33 \\
\hline Share of workers without qualification & 0.06 \\
\hline Share of skilled workers & 0.64 \\
\hline Share of master craftsmen & 0.16 \\
\hline Share of workers with academic qualification & 0.14 \\
\hline \multicolumn{2}{|l|}{ Firm level - structural variables } \\
\hline Firm size: $1-9$ employees & 0.78 \\
\hline Firm size: $10-49$ employees & 0.18 \\
\hline Firm size: $50-499$ employees & 0.04 \\
\hline Firm size: 500 employees and more & 0.00 \\
\hline Agriculture, forestry and fishing & 0.03 \\
\hline Mining and quarrying & 0.00 \\
\hline Manufacturing & 0.10 \\
\hline Electricity, gas, steam and air conditioning supply & 0.00 \\
\hline Water supply; sewerage; waste management and remediation activities & 0.00 \\
\hline Construction & 0.13 \\
\hline Wholesale and retail trade; repair of motor vehicles and motorcycles & 0.22 \\
\hline Transporting and storage & 0.03 \\
\hline Accommodation and food service activities & 0.07 \\
\hline Information and communication & 0.02 \\
\hline Financial and insurance activities & 0.02 \\
\hline Real estate activities & 0.01 \\
\hline Professional, scientific and technical activities & 0.09 \\
\hline Administrative and support service activities & 0.06 \\
\hline Public administration and defense; compulsory social security & 0.01 \\
\hline Education & 0.02 \\
\hline Human health and social work activities & 0.11 \\
\hline Arts, entertainment and recreation & 0.01 \\
\hline Other services activities & 0.06 \\
\hline Observations & 2589 \\
\hline
\end{tabular}


Table A3: Training participation and decision makers' preferences

Dependent variable: The firm trained workers in 2012 (yes/no)

\begin{tabular}{|c|c|c|c|}
\hline & (i): baseline & (ii): (i) $+X_{D m}$ & (iii): (ii) $+X_{i}$ \\
\hline Willingness to take risks & $\begin{array}{c}-0.004 \\
(0.025)\end{array}$ & $\begin{array}{c}-0.003 \\
(0.025)\end{array}$ & $\begin{array}{c}0.023 \\
(0.023)\end{array}$ \\
\hline Procrastination & $\begin{array}{c}-\mathbf{- 0 . 0 3 0} \\
(0.024)\end{array}$ & $\begin{array}{c}-0.022 \\
(0.025)\end{array}$ & $\begin{array}{c}-\mathbf{0 . 0 1 3} \\
(\mathbf{0 . 0 2 2})\end{array}$ \\
\hline Preference for future profits & $\begin{array}{c}0.036 \\
(0.027) \\
\end{array}$ & $\begin{array}{c}0.042 \\
(0.027) \\
\end{array}$ & $\begin{array}{c}0.060^{* *} \\
(0.025) \\
\end{array}$ \\
\hline \multicolumn{4}{|l|}{ Reference: Owner/partner of firm } \\
\hline Interviewed person: CEO & & $\begin{array}{c}0.576^{* * *} \\
(0.159)\end{array}$ & $\begin{array}{c}0.575^{* * *} \\
(0.178)\end{array}$ \\
\hline Interviewed person: Head of department & & $\begin{array}{l}0.679^{* * * *} \\
(0.212)\end{array}$ & $\begin{array}{l}0.820^{\text {**** }} \\
(0.238)\end{array}$ \\
\hline Interviewed person: Head of HRM & & $\begin{array}{l}-0.075 \\
(0.311)\end{array}$ & $\begin{array}{l}-0.123 \\
(0.295)\end{array}$ \\
\hline Interviewed person: Head of HR development & & $\begin{array}{c}0.394 \\
(0.390)\end{array}$ & $\begin{array}{c}0.284 \\
(0.549)\end{array}$ \\
\hline Interviewed person: Business admin. manager & & $\begin{array}{c}0.482 \\
(0.312)\end{array}$ & $\begin{array}{l}0.693^{* *} \\
(0.339)\end{array}$ \\
\hline Interviewed person: Technical manager & & $\begin{array}{c}0.428 \\
(0.495)\end{array}$ & $\begin{array}{c}0.289 \\
(0.493)\end{array}$ \\
\hline Interviewed person: Training manager & & $\begin{array}{c}0.405 \\
(0.273)\end{array}$ & $\begin{array}{c}0.285 \\
(0.306)\end{array}$ \\
\hline Interviewed person: Other function in firm & & $\begin{array}{l}-0.122 \\
(0.230)\end{array}$ & $\begin{array}{l}-0.105 \\
(0.246)\end{array}$ \\
\hline Only decision maker & & $\begin{array}{l}-0.176 \\
(0.147) \\
\end{array}$ & $\begin{array}{c}-0.064 \\
(0.136) \\
\end{array}$ \\
\hline Firm older than 20 years & & & $\begin{array}{c}0.106 \\
(0.121)\end{array}$ \\
\hline Wage management level (in $€$ ) & & & $\begin{array}{l}0.000^{* * *} \\
(0.000)\end{array}$ \\
\hline Works council in firms & & & $\begin{array}{c}0.125 \\
(0.191)\end{array}$ \\
\hline Covered by collective bargaining & & & $\begin{array}{c}0.125 \\
(0.144)\end{array}$ \\
\hline Firm trains apprentices & & & $\begin{array}{l}-0.132 \\
(0.112)\end{array}$ \\
\hline Utilized capacity of firm: Fully used & & & $\begin{array}{c}0.105 \\
(0.133) \\
\end{array}$ \\
\hline Qualification controls & No & No & Yes \\
\hline Firm size controls & No & No & Yes \\
\hline Economic sector controls & No & No & Yes \\
\hline Occupation controls & No & No & Yes \\
\hline Regional controls & No & No & Yes \\
\hline Constant & $\begin{array}{c}0.211 \\
(0.232) \\
\end{array}$ & $\begin{array}{c}0.165 \\
(0.276) \\
\end{array}$ & $\begin{array}{c}-0.867 \\
(0.647) \\
\end{array}$ \\
\hline Pseudo R2 & 0.006 & 0.036 & 0.269 \\
\hline Observations & 2589 & 2589 & 2589 \\
\hline
\end{tabular}

Notes: Probit regressions. Robust standard errors in parentheses. Significance levels: $* \mathrm{p}<0.10, * * \mathrm{p}<$ $0.05, * * * \mathrm{p}<0.01$. Data source is the BIBB CBS 2012. 
Table A4: The number of trained workers and decision makers' preferences

Dependent variable: Number of trained workers in firm

\begin{tabular}{lccc}
\hline \hline & (i): baseline & (ii): (i) + Xind & (iii): (ii) + Xfirm \\
\hline \hline Willingness to take risks & $\mathbf{- 0 . 0 2 0}$ & $\mathbf{- 0 . 0 2 4}$ & $\mathbf{0 . 0 0 8}$ \\
& $(\mathbf{0 . 0 2 1})$ & $(\mathbf{0 . 0 2 0})$ & $(\mathbf{0 . 0 1 6})$ \\
Procrastination & $-\mathbf{0 . 0 1 8}$ & $\mathbf{- 0 . 0 1 9}$ & $\mathbf{- 0 . 0 0 7}$ \\
& $(\mathbf{0 . 0 2 3})$ & $(\mathbf{0 . 0 2 3 )}$ & $(\mathbf{0 . 0 1 5 )}$ \\
Preference for future profits & $\mathbf{0 . 0 3 1}$ & $\mathbf{0 . 0 2 6}$ & $\mathbf{0 . 0 3 1}^{*}$ \\
& $(\mathbf{0 . 0 2 2})$ & $(\mathbf{0 . 0 2 2})$ & $(\mathbf{0 . 0 1 6})$ \\
\hline
\end{tabular}

Reference: Owner/partner of firm

Interviewed person: $\mathrm{CEO}$

$\begin{array}{cc}0.109 & 0.196^{* *} \\ (0.135) & (0.090) \\ 0.285 & 0.460^{* * *} \\ (0.189) & (0.122) \\ -0.810^{* * *} & -0.402^{*} \\ (0.284) & (0.226) \\ 0.212 & 0.768^{*} \\ (0.383) & (0.454) \\ 0.024 & 0.521^{* *} \\ (0.272) & (0.221) \\ -0.132 & 0.085 \\ (0.309) & (0.324) \\ -0.159 & 0.177\end{array}$

Interviewed person: Head of department

$-0.159$

0.177

Interviewed person: Training manager

$(0.325)$

(0.200)

Interviewed person: Other function in firm

$-0.012$

0.161

$(0.214)$

$(0.180)$

Only decision maker

0.104

0.116

(0.115)

(0.082)

Firm older than 20 years

Wage management level (in €)

(0.076)

0.000

(0.000)

Works council in firms

$-0.016$

(0.120)

Covered by collective bargaining

0.033

(0.088)

Firm trains apprentices

$-0.119^{*}$

(0.071)

Utilized capacity of firm: Fully used

0.105

(0.085)

\begin{tabular}{lccc}
\hline Qualification controls & No & No & Yes \\
Firm size controls & No & No & Yes \\
Economic sector controls & No & No & Yes \\
Occupation controls & No & No & Yes \\
Regional controls & No & No & Yes \\
\hline Constant & $-1.393^{* * *}$ & $-1.418^{* * *}$ & $-2.652^{* * *}$ \\
& $(0.207)$ & $(0.228)$ & $(0.454)$ \\
\hline Ln(alpha) & 0.055 & 0.013 & $-0.676^{* * *}$ \\
& $(0.094)$ & $(0.097)$ & $(0.143)$ \\
\hline R2 & 0.001 & 0.006 & 0.100 \\
\hline Observations & 2589 & 2589 & 2589 \\
\hline Notes: Negative binomial regressions. Robust standard errors in parentheses. Significance levels: $*$ p < \\
$0.10, * * \mathrm{p}<0.05, * * * \mathrm{p}<0.01$. Data source is the BIBB CBS 2012.
\end{tabular}


Table A6: Robustness - Subcomponents of training investment

\begin{tabular}{|c|c|c|c|c|}
\hline Dependent Variable in $€$ : & $\begin{array}{c}\text { Absence costs } \\
\left(\mathrm{AC}=\mathrm{h}^{*} \mathrm{w}\right)\end{array}$ & $\begin{array}{c}\text { Internal costs } \\
\text { (IC) }\end{array}$ & $\begin{array}{c}\text { External costs } \\
\text { (EC) }\end{array}$ & $\begin{array}{l}\text { Training } \\
\text { hours }(\mathrm{h})\end{array}$ \\
\hline Willingness to take risks & $\begin{array}{l}27.461^{* *} \\
(13.098)\end{array}$ & $\begin{array}{l}43.411^{* * *} \\
(16.535)\end{array}$ & $\begin{array}{l}31.251^{* *} \\
(14.744)\end{array}$ & $\begin{array}{l}1.513^{*} \\
(0.899)\end{array}$ \\
\hline Procrastination & $\begin{array}{c}-33.670^{* * * *} \\
(12.591)\end{array}$ & $\begin{array}{c}-9.462 \\
(14.166)\end{array}$ & $\begin{array}{l}-28.092^{*} \\
(14.764)\end{array}$ & $\begin{array}{c}-2.343^{* * *} \\
(0.854)\end{array}$ \\
\hline Preference for future profits & $\begin{array}{l}-12.944 \\
(15.417) \\
\end{array}$ & $\begin{array}{c}-\mathbf{0 . 4 5 6} \\
(\mathbf{1 7 . 4 3 5 )} \\
\end{array}$ & $\begin{array}{c}-4.046 \\
(16.571) \\
\end{array}$ & $\begin{array}{l}-1.422 \\
(1.206) \\
\end{array}$ \\
\hline Firm older than 20 years & $\begin{array}{l}0.032^{* *} \\
(0.016)\end{array}$ & $\begin{array}{l}-0.000 \\
(0.021)\end{array}$ & 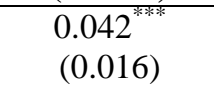 & $\begin{array}{c}0.001 \\
(0.001)\end{array}$ \\
\hline Wage management level (in $€$ ) & $\begin{array}{l}211.514^{*} \\
(123.998)\end{array}$ & $\begin{array}{c}94.039 \\
(127.494)\end{array}$ & $\begin{array}{c}-84.863 \\
(139.154)\end{array}$ & $\begin{array}{c}6.269 \\
(5.478)\end{array}$ \\
\hline Works council in firms & $\begin{array}{r}-110.572^{*} \\
(64.829)\end{array}$ & $\begin{array}{c}78.330 \\
(91.626)\end{array}$ & $\begin{array}{l}-30.053 \\
(63.104)\end{array}$ & $\begin{array}{l}-7.795 \\
(4.863)\end{array}$ \\
\hline Covered by collective bargaining & $\begin{array}{l}-63.320 \\
(60.545)\end{array}$ & $\begin{array}{c}-202.530^{* * * *} \\
(69.972)\end{array}$ & $\begin{array}{c}88.675 \\
(58.686)\end{array}$ & $\begin{array}{l}-4.966 \\
(4.488)\end{array}$ \\
\hline Firm trains apprentices & $\begin{array}{c}28.562 \\
(90.114)\end{array}$ & $\begin{array}{c}-164.279^{*} \\
(95.673)\end{array}$ & $\begin{array}{c}31.549 \\
(75.362)\end{array}$ & $\begin{array}{c}7.263 \\
(7.598)\end{array}$ \\
\hline $\begin{array}{l}\text { Utilized capacity of firm: Fully } \\
\text { used }\end{array}$ & $\begin{array}{c}-124.879^{*} \\
(68.532)\end{array}$ & $\begin{array}{l}97.138^{*} \\
(50.447)\end{array}$ & $\begin{array}{l}-65.013 \\
(49.399)\end{array}$ & $\begin{array}{c}-10.261^{*} \\
(5.368)\end{array}$ \\
\hline Only decision maker & Yes & Yes & Yes & Yes \\
\hline Function interviewed person & Yes & Yes & Yes & Yes \\
\hline Qualification controls & Yes & Yes & Yes & Yes \\
\hline Firm-size controls & Yes & Yes & Yes & Yes \\
\hline Economic sector controls & Yes & Yes & Yes & Yes \\
\hline Occupation controls & Yes & Yes & Yes & Yes \\
\hline Regional controls & Yes & Yes & Yes & Yes \\
\hline Constant & $\begin{array}{c}117.082 \\
(305.508) \\
\end{array}$ & $\begin{array}{c}-1178.536^{* * *} \\
(411.692) \\
\end{array}$ & $\begin{array}{l}-424.854 \\
(369.613) \\
\end{array}$ & $\begin{array}{c}30.352 \\
(21.249) \\
\end{array}$ \\
\hline Pseudo R2 & 0.017 & 0.040 & 0.022 & 0.022 \\
\hline Observations & 1768 & 1768 & 1768 & 1768 \\
\hline Left-censored (0) observations & 25 & 1117 & 125 & 25 \\
\hline
\end{tabular}


Table A7: Robustness - Sample restricted to sectors with large quota of male managers

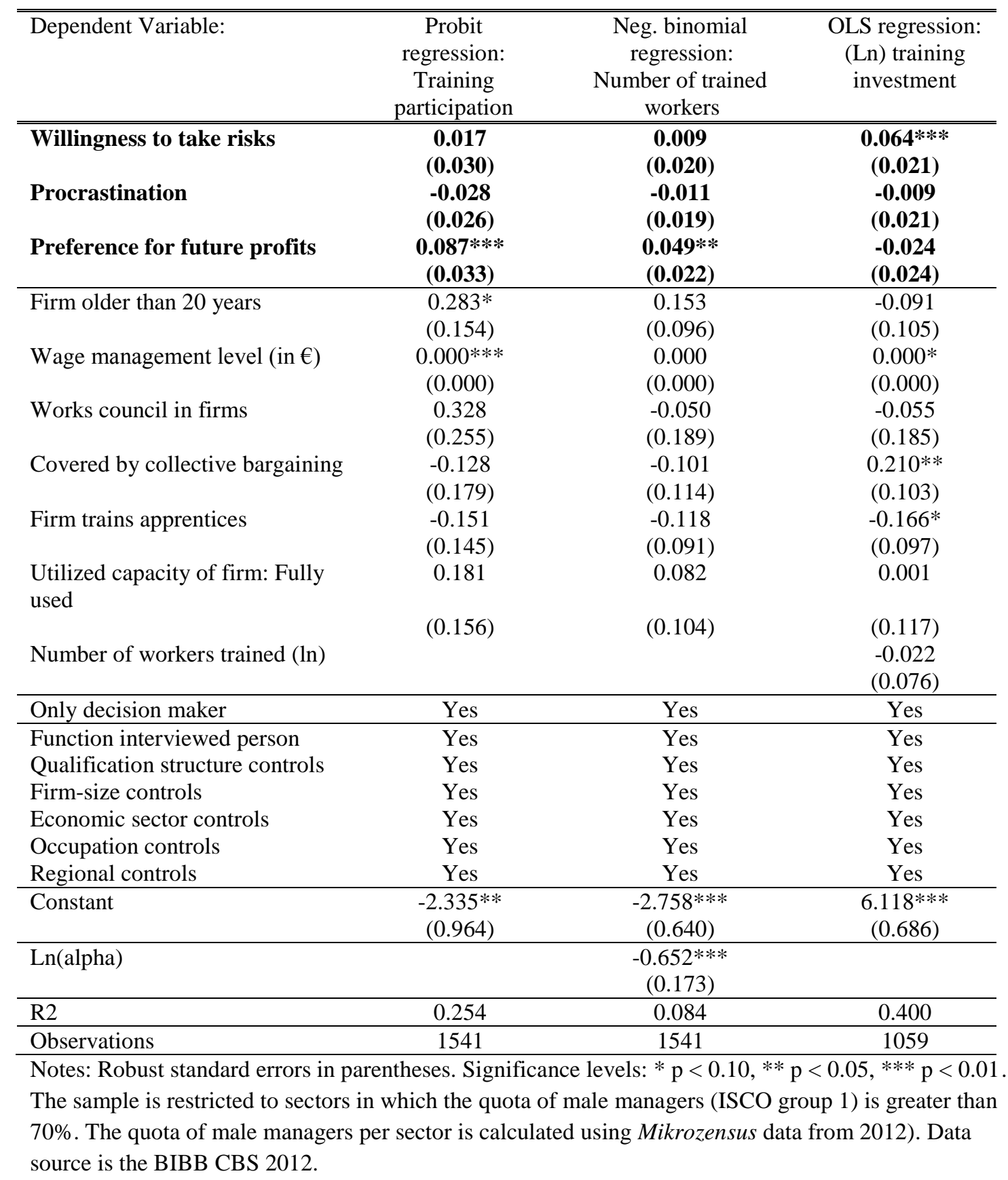


Table A8: Robustness - Sample restricted to firms with external training only

Dependent Variable: (Ln of) Training investments per trained worker

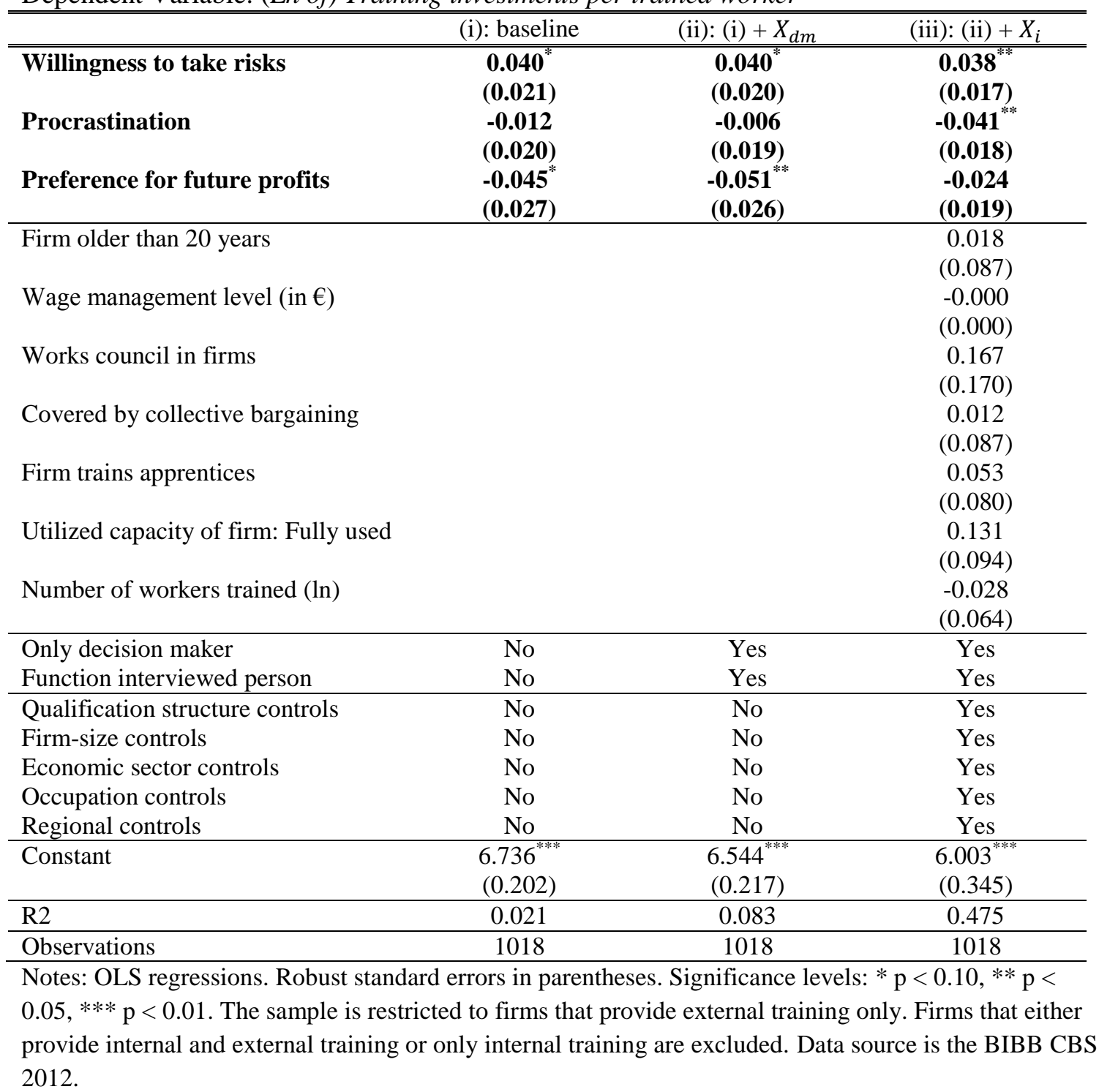

